\title{
Capital Market Integration and Industrial Structure: The Case of Australia, Canada and the United States
}

\author{
Robert W. Faff \\ Monash University \\ Usha R. Mittoo \\ University of Manitoba
}

\begin{abstract}
Using a matched sample design where companies are matched by size and industry from Australian, Canadian and US capital markets, we investigate whether capital market integration varies across industries and by geographical proximity. The tests are conducted in the multi-factor pricing framework over the 1983-1997 period. Our evidence supports two main findings. First, the pricing of Australian stocks is different from that of their Canadian and U.S. counterparts. The Australian stocks are priced in a partially segmented global market whereas the Canadian stocks are priced in a regionally integrated North American stock market. Second, global industry stocks such as oil and mining stocks are priced in a relatively integrated capital market while regional industry stocks such as consumer and capital goods stocks are priced in segmented markets. This evidence suggests that industry and geographical distance may proxy factors that may be relevant in international asset pricing.

- JEL Classifications: F 30, G12, G15

- Key words: Integration, Segmentation, Industrial structure, Multi-Country study

\footnotetext{
*Corresponding address: Professor Robert W. Faff Monash University, Department of Accounting and Finance, CLAYTON, Victoria 3800, Australia. Ph. +61 39905 2381. Fax. +61 39905 2339.; Usha R. Mittoo, Asper School of Business, University of Manitoba Accounting and Finance Department, 660 Drake Ctr, Winnipeg, MB R3T2N2 Canada. E-mail: umittoo@ms.umanitoba.ca (2003-Center for International Economics, Sejong Institution, All Rights Reserved.
} 


\section{Introduction}

In this paper, we investigate some possible sources of unequal integration across securities in three closely aligned western economies, namely, Australia, Canada and the US. Specifically, we focus on examining the role of industry and geographical distance on the degree of integration across countries. Our selection of countries is appealing because of the unique pair-wise comparisons in industrial structure, economic linkages and geographical proximity that it allows. While Australia and Canada have common industrial structure, they have minimal economic and trade linkages. Australia and the US, on the other hand, have dissimilar industrial structures with strong trade relations. Finally, the US and Canada also have dissimilar industrial structures but have strong economic and trade linkages as well as close geographical proximity.

Our study is motivated by two different strands of literature. First, a large number of studies in recent years have investigated whether security markets of different countries are integrated or segmented using standard asset pricing models. ${ }^{1}$ Despite the strong empirical evidence of integration in many of these studies, some puzzling questions that are inconsistent with this evidence remain unanswered. For example, a strong home bias observed in the holdings of "investors" portfolios is inconsistent with the efficient portfolio diversification assumption that underlies the standard asset pricing models. ${ }^{2}$ Further, while bilateral tests of integration between pairs of countries are supportive of integration, the tests in the multi-country setting are less informative because the performance of standard asset pricing models declines as the number of sample countries or securities is increased. ${ }^{3}$ For example, Cho, Eun and Senbet (1986) reject the joint hypothesis that markets are integrated and the International

\footnotetext{
${ }^{1}$ See Stulz (1995) for an integrative survey on international portfolio choice and asset pricing.

${ }^{2}$ See French and Poterba (1991), Cooper and Kaplanis (1994), and Tesar and Werner (1995) for evidence of the home bias. Stulz (1995) observes that if the home bias is the outcome of investors optimization, existing tests of international asset pricing models do not have enough power to provide support for this view. Tesar and Werner (1995) show that transaction costs are an unlikely explanation of the home bias since the turnover of these assets is at least as high as the domestic portfolios.

${ }^{3}$ Jorion and Schwartz (1986), Gultekin, Gultekin and Penati (1989), Campbell and Hamao (1992), Mittoo (1992), and Koutoulas and Kryzanowski (1994) conduct bilateral tests of integration and find evidence consistent with segmentation in earlier periods of strict capital controls but a move toward integration in the recent time periods.
} 
Arbitrage Pricing Theory (APT) is valid using sample firms from 11 countries, but fail to reject this hypothesis in subsets of countries in their sample. They observe that it is plausible that the traditional asset pricing models such as the APT may only hold locally or regionally in segmented capital markets but not globally. ${ }^{4}$ These puzzling findings suggest that some important determinants of market integration may not be fully captured in the traditional asset pricing models. In this paper, we examine the sensitivity of the tests of integration in the multi-factor pricing framework to two factors, industry and geographical proximity, by conducting joint tests of integration for all the three sample countries as well as bilateral tests between pairs of countries.

Our choice of factors is motivated by another strand of literature relating to the determinants of the international stock returns. Many recent studies have investigated the role of industry in international portfolio diversification and most conclude that an industry factor plays a significant role in explaining the volatility and correlations of country index returns. ${ }^{5}$ Griffin and Karolyi (1998) also document significant differences in risk factors across industries. They find that for industries that do not produce goods traded internationally, country factors play a dominant role in explaining the variation of the index while for industries which produce goods traded internationally, the industry factor is an important determinant of the index variance. We extend this enquiry further by studying whether the pricing of the risk factors also varies between global and regional/local industry groupings. We define global industries as those sectors that produce goods that are traded globally such as Oil and Gas whereas regional/local industries are defined as those industries that serve primarily the local or regional markets such as consumer goods and service industries. ${ }^{6}$

The role of geographical distance in explaining the home bias has also been

\footnotetext{
${ }^{4}$ Korajczyk and Viallet (1989) compare the performance of domestic and international versions of several alternative asset pricing models in a sample of over 4000 securities from four countries and find that the Capital Asset Pricing Model (CAPM) leads to large pricing errors for small stocks and the performance of the international APT depends on the regime for barriers to international investment. Choi and Rajan (1997) document a reversal of results of integration for some countries when a threefactor model is used instead of a two-factor pricing model in a sample of 337 stocks drawn from seven non-US major capital markets.
}

${ }^{5}$ Lessard (1974) first examined the role of industrial composition in explaining the variation in stock return across countries. More recently, Solnik and de Freitas (1988), Roll (1992), Heston and Rouwenhorst (1994), Grinold, Rudd and Stefek (1989) and Drummen and Zimmermann (1992), and Griffin and Karolyi (1998) examine the role of industrial structure in international diversification.

${ }^{6}$ It is acknowledged that this global-regional distinction is somewhat arbitrary and, as such, represents a potential limitation of our analysis. 
investigated in many recent studies. ${ }^{7}$ Coval and Moskowitz (1999) document that US investment managers exhibit a strong preference for locally headquartered firms in their domestic portfolio. Extrapolating their findings to the international scale, they suggest that as much as one-third of the home bias puzzle may only be a feature of a geographical proximity preference and a relative scale of world economy, rather than a consequence of national borders. They argue that investors may prefer proximate investments for many reasons including easy information availability or desire to hedge against price increases in local services or in goods not easily traded outside the local area. Portfolio managers also commonly use industry and geographical diversification as a basis for international diversification. ${ }^{8}$ Tesar and Werner (1995) examine the portfolio choices of Canadian and US investors and find that geographical proximity seems to be an important ingredient in the international portfolio decision. Arshanapalli, Doukas, and Lang (1997) investigate the behavior of nine industry groups in three geographical regions and find that intra-industry volatilities are not similar across regions and consequently intra-industry diversification across regions appears to be an effective strategy for portfolio risk reduction. We contribute to this literature by examining whether the geographical proximity and economic and trade linkages are also a source of unequal integration across securities.

Differential pricing based on industry or geographical region can be motivated in "Mertons" (1987) model in which investors generally are "aware" of only a subset of available securities depending on individual investors degree of recognition of different securities. This model predicts that investor recognition plays an important role in asset pricing and that the expected return on a security decreases as the size of the investor base for that security increases. It can be argued that firms in global industries would have more publicly available information and consequently a larger investor base compared to their regional or local industry counterparts. More publicly available information about a firm is also likely to reduce asymmetry of information between foreigner and local investors which is hypothesized to be a major factor in the asymmetric information-based explanations of the international

\footnotetext{
${ }^{7}$ See Huberman (2000), Froot et al. (2001) and Portes and Rey (2001) for the role of geographical distance in portfolio investments decisions.

${ }^{8} \mathrm{~A}$ recent example is the introduction of the Dow Jones World Stock index on January 5, 1993 to provide a comprehensive measure of stock performance. It has been divided primarily on a geographical and industrial basis for comparative purposes. There are nine industrial sectors, Basic materials, Consumer/ cyclical, consumer/non-cyclical, Energy, Financial, Industrial, Technology, Utilities and Independent and three regions, the US, Europe and Pacific countries.
} 
capital market segmentation. ${ }^{9}$ Investors are also likely to be more familiar about firms operating in their geographical regions relative to those operating in distant regions. Smaller open economies such as Canada may thus be regionally integrated rather than globally integrated if more of their trade is conducted regionally.

We conduct tests of integration using 64 securities from each sample country matched on the basis of size and industry. Specifically, we focus on three questions: (a) whether the three capital markets are integrated with global markets and with each other; (b) whether the degree of integration varies across geographical distance; and (c) whether the degree of integration varies across global and regional industries. To the extent that industrial structure is a relevant factor in international asset pricing, Canadian and Australian matched stocks should have similar prices. On the other hand, if geographical proximity and economic and trade linkages are important determinants of asset pricing, Canadian and US stocks should have similar prices.

Our evidence supports that the price of risk in our sample is not the same across the three countries. The tests show that Australian stocks are priced in different markets than their Canadian or US counterparts. Further, our evidence also suggests that the global industry stocks are priced in a relatively integrated market compared to the regional industry stocks. These findings suggest that both industry and geographical proximity may be potentially important in international asset pricing.

The remainder of the paper is organized as follows. Section I outlines the sample chosen, while section II discusses the empirical framework. In section III we present and discuss the empirical results, and finally, in section IV we present a summary and conclusions.

\section{Matched Sample Selection and Data}

\section{A. Characteristics of the Sample Countries}

The three sample countries have many common and distinct features. While all have large geographical areas, Australia and Canada have a small population base. Moreover, for Australia and Canada natural resources and agriculture are the main industrial sectors and these comprise a major portion of the exports for both

\footnotetext{
${ }^{9}$ Gehrig (1993), Brennan and Cao (1997), and Kang and Stulz (1997) develop models based on asymmetry of information between foreign and local investors.
} 
Table 1. A Comparison of Australian, Canadian and US Capital Markets

\begin{tabular}{lccc}
\hline & Australia & Canada & United States \\
\hline $\begin{array}{l}\text { Total Market } \\
\text { Capitalization (\$US) }\end{array}$ & $\$ 312$ billion & $\$ 486$ billion & $\$ 8,484$ billion \\
World Ranking & 10 & 6 & 1 \\
\hline $\begin{array}{l}\text { Total Value Traded } \\
\text { \$US) }\end{array}$ & $\$ 145$ million & $\$ 265$ million & $\$ 7,121$ million \\
World Ranking & 15 & & 1 \\
\hline $\begin{array}{l}\text { Number of Listed } \\
\text { Companies }\end{array}$ & 1,135 & 1,265 & 8,800 \\
World Ranking & 7 & & 1 \\
\hline $\begin{array}{l}\text { Average Company Size } \\
\text { (\$US) }\end{array}$ & $\$ 275$ million & $\$ 384$ million & $\$ 1,000$ million \\
World Ranking & & & 6 \\
\hline
\end{tabular}

Note: End of 1996 data

Source: Emerging Markets Factbook 1997

countries. The one exception to this is that Australia imports petroleum products while Canada exports oil and natural gas. The size of the Australian economy is, however, much smaller than its Canadian counterpart. Based on the 1993 Gross Domestic Product figures, the Australian economy [\$US 292 billion] is less than half the size of the Canadian economy [\$US570 billion]. ${ }^{10}$ Although, Australia and Canada have world rankings of fifteenth and ninth respectively in terms of the total value traded, the Australian foreign trade (exports and imports) is less than one third of Canadian trade. For example, in 1993 Australia had exports of about \$US42 billion compared with "Canada's" total of around \$US144 billion. These differences could be attributed partly to the geographic isolation of Australia which is in stark contrast to Canadas juxtaposition with the large and diversified US economy. Hence, it is not surprising to find that the US is the major trading partner of Canada, whereas Japan and other South Asian countries form the major trading partners for Australia.

Table 1 also shows that the total market capitalization of the Canadian market is also about one and a half times larger than Australias [ $\$ 486$ billion versus $\$ 312$ billion], although they both have a world ranking in the top ten. Further, while the

\footnotetext{
${ }^{10}$ The figures referred in this section are 1993 figures sourced from Political Risk Service (1994).
} 
two countries rank very closely (sixth and seventh) in terms of the number of listed companies, the Canadian firms are, on average, considerably larger than their Australian counterparts (\$US384 million versus \$US275 million). Again, geographical distance could also play a role in capital market development similar to that in the international capital flows documented in several recent studies. ${ }^{11}$ It is not surprising that the US overwhelms both Canada and Australia in all comparisons and that the US world ranking is number one on the first three measures, it is noteworthy that the US only ranks sixth in terms of average company size. Overall, these differences suggest that factors such as firm size may vary across the countries and need to be controlled in tests of integration. We undertake this by employing matched firms in the three countries that is discussed in the next section.

\section{B. Matching Process}

The matching process for generating our size and industry matched dataset involved two stages. A summary of the outcome of this process is presented in Table 2 (Panel A). In the first stage, a pool of eligible Australian and Canadian firms based on liquidity and size was generated. Our starting point was to consider those companies having a full return history over our chosen sample period, 1983 to $1992 .^{12}$ In the case of Australia, a total of 142 firms met this criterion, as opposed to only 74 Canadian firms. To enlarge the pool of eligible Canadian firms, we included additional Canadian firms with a maximum of two missing observations. As a result, an additional 38 firms were identified, thus achieving a total of 102 Canadian firms. ${ }^{13}$ The size of a firm was proxied by the book value of the firms total assets as on December 31, 1992. Since the Australian sample firms

\footnotetext{
${ }^{11}$ See for example, Froot et al. (2001), and Portes and Rey (2001).

${ }^{12}$ Since infrequent trading is a major problem in the Australian and Canadian data, this screen is used to minimize this problem but it is likely to introduce a survivorship bias in our data. However, since this screen is used across all countries, the bias is likely to be similar across the three countries.

${ }^{13}$ In the few cases where Canadian companies had multiple classes of shares, we selected the class of shares with the highest trading volume.

${ }^{14}$ December 1992 was used because of difficulty in obtaining size data for many firms in the earlier time period. Deleting Australian firms with asset value less than AUS \$50 million creates a potential bias in our sample because more Australian firms that are successful are likely to be included, resulting in a potential higher mean return for these firms compared to their US and Canadian counterparts. To address this concern, we also test the robustness of our results in the 1993-97 period and find that the results are qualitatively similar to that in the 1983-92 period.
} 
Table 2. Summary of Matched Sample Selection Process and Industry Representation

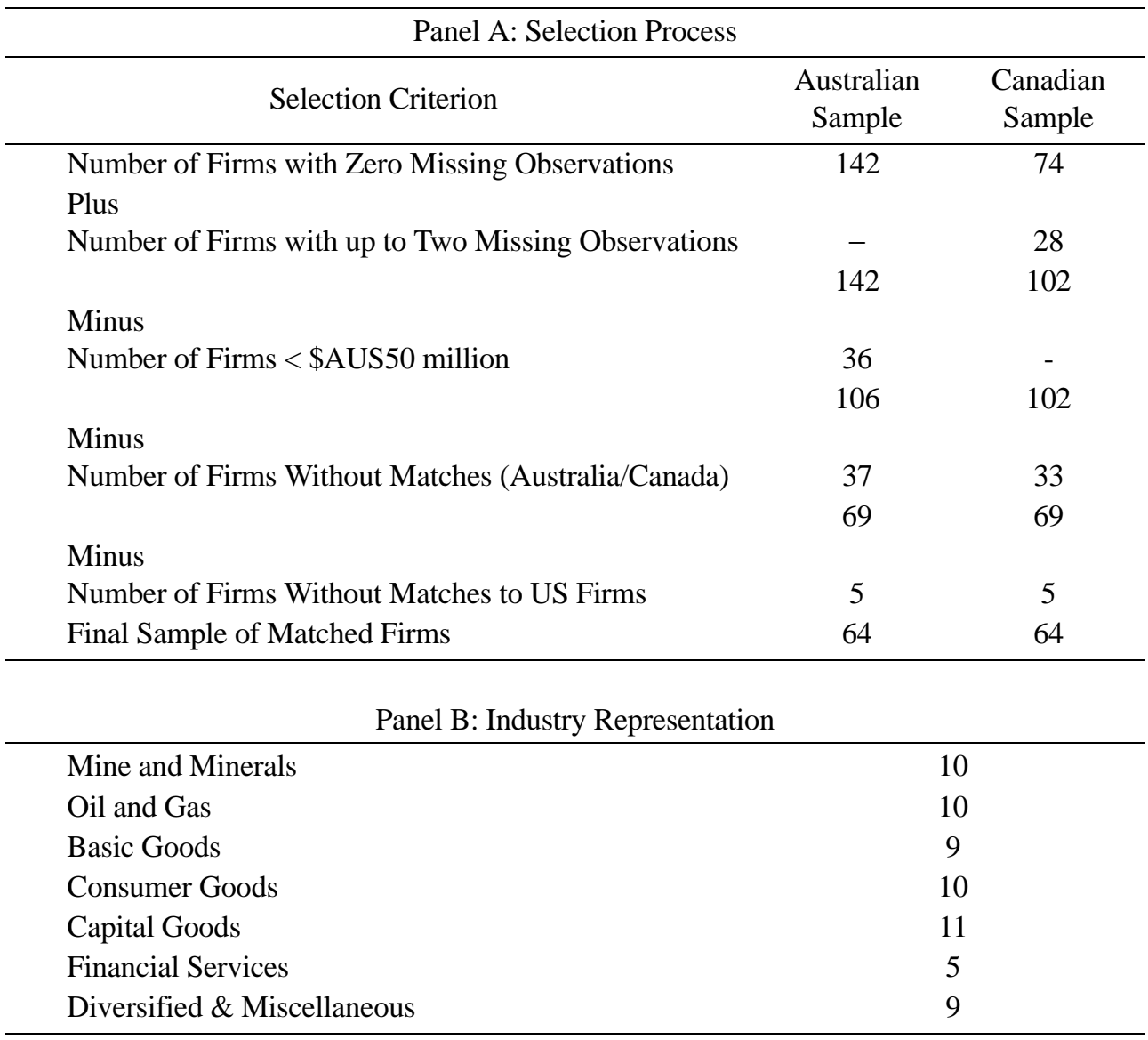

are, on average, much smaller than Canadian firms, to obtain similar size firms, we included only those Australian firms that had a size of \$AUS 50 million. ${ }^{14}$ As 31 Australian firms failed this size condition; a sample of 106 Australian firms remained.

The second stage involved matching the firms from the eligible pool on the basis of size and industry. The business description and total asset size for eligible firms were obtained from a variety of sources including Moody International Manual 1994, Compustat, Compact disclosure, various Australian company Annual Reports, Jobsons Yearbook of Australian Companies, Jobsons Mining

\footnotetext{
${ }^{15}$ The SIC classification was also used wherever the information was available to cross check our matching process. However, since the SIC classification for some firms could vary substantially across different sources, for all firms the final matching was completed by examining business description.
} 
Yearbook, and the Business Whos Who of Australia. ${ }^{15}$ All Australian and Canadian firms in the eligible set were assigned to one of the seven broad industry categories based on their business description: (a) mines and minerals; (b) oil and gas; (c) basic goods; (d) consumer goods; (e) capital goods; (f) financial services; and $(\mathrm{g})$ diversified and miscellaneous. ${ }^{16}$

Within each industry sector, firms were first matched by business description and then by size. For each company in the same business, firms that were closest in size were matched without any restrictions on the size. Appropriate Canadian matches were found for only 69 Australian firms.

The final step involved matching the US firms. The search for the US matches was limited to the firms that were listed either on the New York Stock Exchange (NYSE) or the American Stock Exchange (AMEX) and had continuous data availability for the entire period. Unfortunately, in the case of five Australian firms, mostly in the mines and minerals industry sector, appropriate US matches were not available. Accordingly, our final sample in the 1983-92 period consists of 192 firms, 64 from each country. The distribution of our final sample of firms across the seven industry groups is reported in Table $2 .{ }^{17}$ Across countries, most firms are well matched by size. Both parameter t-test and non-parameter Wilcoxon Signed-ranked tests fail to reject the equality of means and medians respectively at the conventional significance levels for the matched firms across all country pairs. Across industry groups, however, the average size of firms varies substantially. For example, a typical firm in the financial services sector is almost ten times the size of an average sample firm, and almost 100 times the size of an average capital goods firm.

The stock returns data used in this study are sampled on a monthly basis. The Australian stock returns data were obtained from the Price Relative File of the

\footnotetext{
${ }^{16}$ These categories are similar to those employed by Roll (1992), Grinold, Rudd, and Stefek (1989) as well as by the Dow Jones World Stock Index but are fewer in number, reflecting the industrial structure of Australia and Canada that is dominated by resource based sectors.

${ }^{17}$ The availability of appropriate matches varied by industry and country. The mines and minerals sector was the most difficult sector for finding matches. Starting with 20 Australian firms, appropriate matches could be found for only ten firms. The unavailability of a sufficient number of the US firms in this sector and the larger size of most Canadian firms were the major obstacles in finding appropriate matches. The oil and gas sector was a relatively easy sector to find matches. The basic industry sector included firms in steel, paper and construction industries. Consumer goods firms deal mostly with food and beverages while chemical and engineering firms dominate the capital goods sector. The financial services sector is comprised mainly of banks, while the diversified and miscellaneous sector is comprised mostly of transportation, media, and diversified firms. With the exception of the financial services sector, each sector comprises approximately 10 sample firms.
} 
Centre for Research in Finance (CRIF) at the Australian Graduate School of Management and the Canadian data were extracted from the Canadian Financial Markets Research Centre (CFMRC) database at the University of Manitoba. The US company data were obtained from the Center for Research in Securities Prices (CRSP) data tape. Stock returns are monthly rates of capital gains and dividends in local currency terms. These were converted to common US dollar returns using exchange rates sourced from the International Financial Statistics.

\section{Empirical Framework}

To compare whether the price of risk is the same across the three samples we need to specify an equilibrium model of asset pricing. We use the multi-factor pricing model that is commonly employed in most previous studies as the benchmark for comparing risk and return.

\section{A. Multi-factor Pricing Framework}

A basic assumption underlying the Arbitrage Pricing Theory (APT) is that the asset returns follow a multi-factor model:

$$
R_{i t}=E_{i t}+\sum_{k=1}^{S} \beta_{i k} \delta_{k t}+u_{i t}
$$

where $R_{i t}$ and $E_{i t}$ are the actual and the expected returns on asset i respectively in period t, $\delta_{k t}$ is the kth risk factor with mean zero, $\beta_{i k}$ is the sensitivity of asset $i$ to the kth factor, and $u_{i t}$ is a normally distributed error term with mean zero. Assuming no arbitrage opportunities and some additional conditions (Connor (1984)), the expected returns on asset i can be written as

$$
E_{i t}=R_{F t}+\sum_{k=1}^{s} \lambda_{k} \beta_{i k}
$$

where $R_{F t}$ is the risk free rate in period t and $\lambda_{k}$ is the risk premium associated with the kth factor.

The empirical version of the model is an extension of Gultekin, Gultekin and Penati (1989) and Mittoo (1992)'s two-country case. We assume that there are $\mathrm{N}+3$ securities traded in the three countries. Three securities are the Australian, Canadian and US risk-free assets, respectively, and the remaining $\mathrm{N}$ assets are Australian, Canadian and US stocks with prices measured in US dollar terms. The empirical version of the model is formulated by substituting (2) into (1): 


$$
R_{i r}^{J}=R_{F t}^{J}+\sum_{k=1}^{S} \lambda_{k}^{J} \beta_{i k}^{J}+e_{i t}^{J}, \quad J=A U S, C D N, U S
$$

where superscripts, AUS, CDN and US, denote the Australian, Canadian and US stocks, respectively, and $e^{J}{ }_{i t}=\Sigma^{S}{ }_{k=1} \beta^{J}{ }_{i k} \delta_{k t}+u^{J}{ }_{i t}$ is an error term. We use the US dollar as the numeraire currency. Market integration across the three countries implies the restriction:

$$
\lambda_{k}^{A U S}=\lambda_{k}^{C D N}=\lambda_{k}^{U S}, \quad R_{F}^{A U S}=R_{F}^{C D N}=R_{F}^{U S}
$$

Bilateral tests are also performed.

A difficulty of testing in the APT framework is that there is no agreement on the empirical implementation and testing of multi-factor models. Accordingly, we use two methods that are commonly employed in the empirical testing of the multifactor model, namely, the pre-specified factors and factor analytic approaches. Tests are performed using individual securities as well as in different time periods to test the robustness of the results to alternative testing procedures and model specification errors.

\section{A.1. Pre-Specified Factors Approach}

We specify six economic variables as potential sources of risk for our sample of securities. The first factor is the world stock market index, denoted by INTMKT and proxied by the Morgan Stanley Capital International (MSCI) index, adjusted for dividends. The next three factors are purely domestic country factors and these are proxied by those parts of the Australian, Canadian and US market indices that are orthogonal to the INTMKT index, denoted by RESAUS, RESCDN and RESUS, respectively, and are measured in US dollars. The data on the country stock market indices are collected from the Morgan Stanley Stock Indices. These data include the effects of dividends and stock split adjustments. The two final factors are the percentage change in oil prices and in the metal price index, and they proxy the industry factors that may be dominant in the primarily resourcebased economies of Australia and Canada. ${ }^{18}$ The data for these series and the monthly rate of change in the local currency per unit of dollar are obtained from the International Financial Statistics.

Table 3 provides the summary statistics for the pre-specified economic factors in the 1983-92 and 1993-97 periods. The estimated means for all factors in the 1983-92 period are close to zero, with the exception of the world stock index

\footnotetext{
${ }^{18}$ It should be recognized that this set of factors is somewhat limited and hence, represents a limitation of the analysis.
} 
Table 3. Summary Statistics: Prespecified Economic Factors

The economic factors are:

\begin{tabular}{|c|c|}
\hline INTMKT: & $\begin{array}{l}\text { Monthly rate of return on the Morgan Stanley Capital International (MSCI) } \\
\text { index. }\end{array}$ \\
\hline RESMETAL: & Percentage change in the metal index orthogonal to the INTMKT. \\
\hline RESOIL: & Percentage change in the oil prices (US\$) orthogonal to the INTMKT. \\
\hline RESUS: & $\begin{array}{l}\text { Monthly return on the purely domestic component of the US market index } \\
\text { (US\$) orthogonal to INTMKT. }\end{array}$ \\
\hline RESAUS: & $\begin{array}{l}\text { Monthly return on the purely domestic component of the Australian market } \\
\text { index (US\$) orthogonal to INTMKT. }\end{array}$ \\
\hline RESCDN: & $\begin{array}{l}\text { Monthly return on the purely domestic component of the Canadian market } \\
\text { index (US\$) orthogonal to INTMKT. }\end{array}$ \\
\hline
\end{tabular}

\section{Panel A: February 1983-December 1992}

\begin{tabular}{lrrrrrrrr}
\hline \multicolumn{8}{c}{ Correlations } \\
\hline METAL & 0.0000 & 0.103 & 1.00 & & & & \\
OIL & 0.000 & 0.029 & -0.18 & 1.00 & & & & \\
INTMKT & 0.013 & 0.045 & 0.00 & -0.00 & 1.00 & & & \\
RESUS & -0.00 & 0.072 & 0.04 & -0.04 & 0.00 & 1.00 & & \\
RESAUS & -0.00 & 0.030 & 0.14 & 0.12 & 0.00 & 0.13 & 1.00 & \\
RESCDN & -0.00 & 0.036 & 0.15 & 0.40 & 0.00 & 0.52 & 0.40 & 1.00 \\
\hline
\end{tabular}

Panel B: January 1993-December 1997

\begin{tabular}{lrrrrrrrr}
\hline \multicolumn{8}{c}{ Correlations } \\
\hline & MEAN & S.D. & METAL & OIL & INTMKT & RESUS & RESAUS RESCDN \\
\hline METAL & 0.000 & 0.036 & 1.00 & & & & \\
OIL & 0.000 & 0.062 & 0.111 & 1.00 & & & & \\
INTMKT & 0.009 & 0.031 & 0.00 & 0.00 & 1.00 & & & \\
RESUS & 0.000 & 0.021 & -0.05 & -0.17 & 0.00 & 1.00 & & \\
RESAUS & 0.000 & 0.035 & 0.13 & -0.06 & 0.00 & -0.20 & 1.00 & \\
RESCDN & 0.000 & 0.029 & -0.11 & -0.17 & 0.00 & 0.37 & 0.28 & 1.00 \\
\hline
\end{tabular}

(Panel A). Most correlations are also small but there are a few exceptions. The highest correlation is between RESCDN and RESUS (0.52), which reflects high economic integration between the two economies. RESCDN and RESAUS are also highly correlated (0.4) and both are also highly correlated to the METAL index, suggesting influence of a common industrial structure in Australia and Canada. OIL is also highly correlated with RESCDN but less correlated with RESAUS and RESUS. This probably reflects the status of Canada as an oil exporter (in contrast to the US and Australia, which are both net importers of oil). 
The pattern of correlations in the 1993-97 period (Panel B) is very similar to that in the 1983-92 period with some exceptions; OIL is negatively correlated with all factors and RESUS is negatively correlated with RESAUS.

A two-step procedure is employed to estimate equation (2); first betas and then the risk premia are estimated. The same sample periods are used in both steps. Mean values of stock returns are used as the dependent variables in the crosssections of the estimated factor loadings. The Australian, Canadian and US risk premia are estimated jointly with a seemingly unrelated regression model:

$$
\begin{gathered}
\bar{r}^{A U S}=\lambda_{0}^{A U S}+\hat{B}^{A U S} \lambda^{A U S}+v^{A U S} \\
\bar{r}^{C A N}=\lambda_{0}{ }^{C A N}+\hat{B}^{C A N} \lambda^{C A N}+v^{C A N} \\
\bar{r}^{U S}=\lambda_{0}{ }^{U S}+\hat{B}^{U S} \lambda^{U S}+v^{U S}
\end{gathered}
$$

where $\bar{r}_{i}$ is the mean return for stock i over the sample period and $\hat{B}$ is the estimated factor loading matrix. Wald tests are used to test the equality of the Australian, Canadian and US risk premia, as expected under the null hypothesis of integrated markets.

\section{A.2. Factor-Analytic Approach}

The approach used here is very similar to the prespecified factors case discussed above and involves a three-step procedure. In the first step, five-factors are extracted from twenty-one portfolios (three countries times seven industry sectors) in the sample period and factor scores are computed. In the second step, factor betas are estimated with a multiple regression on five factors as the independent variables. In the third and final step, the risk premia are estimated cross-sectionally using the estimated mean returns of the Australian, Canadian and US stocks as the dependent variable and the security betas of the 64 Australian, Canadian and US matched stocks as the independent variables. As was the case above, Wald tests are employed to test the equality of the Australian, Canadian and US risk premia.

\section{B. Descriptive Statistics}

Tables provide descriptive statistics of the industry portfolios formed from the sample securities from each country in the 1983-92 period. The Australian portfolios, with the exception of the mining portfolio, have the highest mean return compared to their Canadian and US counterparts but the differences in means are not statistically significant (Panel B). The range of average returns 
Table 4-a. Descriptive Statistics: Country and Industry Portfolios, February 1983 December 1992

\begin{tabular}{|c|c|c|c|c|c|c|c|}
\hline \multicolumn{8}{|c|}{ Panel A: Mean and Standard Deviations } \\
\hline \multirow{2}{*}{ Portfolio } & \multirow{2}{*}{$\begin{array}{c}\text { Number } \\
\mathrm{N}\end{array}$} & \multicolumn{2}{|c|}{ Australia } & \multicolumn{2}{|c|}{ Canada } & \multicolumn{2}{|c|}{ US } \\
\hline & & Mean & S.D. & Mean & S.D. & Mean & S.D. \\
\hline Mine and Minerals & 10 & 0.00159 & 0.1137 & -0.0005 & 0.0736 & 0.00191 & 0.0693 \\
\hline Oil and Gas & 10 & 0.0051 & 0.1043 & 0.00431 & 0.065 & -0.00001 & 0.0731 \\
\hline Consumer Goods & 9 & 0.0138 & 0.0769 & 0.00789 & 0.0501 & 0.01357 & 0.0522 \\
\hline Capital Goods & 10 & 0.0131 & 0.0739 & 0.0051 & 0.0634 & 0.00398 & 0.0666 \\
\hline Basic Goods & 10 & 0.009 & 0.0855 & 0.00108 & 0.0614 & 0.00044 & 0.0754 \\
\hline Financial Service & 5 & 0.0125 & 0.0709 & 0.00112 & 0.057 & 0.00394 & 0.0712 \\
\hline Diversified & 9 & 0.01413 & 0.0865 & 0.0053 & 0.0602 & 0.00281 & 0.0652 \\
\hline Stock Market Index & & 0.01462 & 0.0792 & 0.00805 & 0.0476 & 0.01326 & 0.0455 \\
\hline
\end{tabular}

Panel B: Tests of the hypothesis of no difference in means of the matched industry portfolios (t-statistics)

\begin{tabular}{lccc}
\hline \multicolumn{1}{c}{ Portfolio } & $\begin{array}{c}\text { Australian } \\
\text { Canadian }\end{array}$ & Australian & Canadian \\
& 0.28 & -0.05 & US \\
\hline Mine and Minerals & 0.11 & 0.59 & -0.63 \\
Oil and Gas & 0.925 & 0.032 & 0.88 \\
Consumer Goods & 1.21 & 1.25 & -1.49 \\
Capital Goods & 1.09 & 1.17 & 0.24 \\
Basic Goods & 0.18 & 1.13 & 0.12 \\
Financial Service & 1.29 & 1.51 & 1.18 \\
Diversified & 1.08 & -1.73 & 0.52 \\
Stock Market Index & & & -1.73 \\
\hline
\end{tabular}

Panel C: Bartlett Test of the hypothesis of no difference in variance of the matched portfolios (F approximation)

\begin{tabular}{llll}
\hline \multicolumn{1}{c}{ Portfolio } & $\begin{array}{c}\text { Australian } \\
\text { Canadian }\end{array}$ & $\begin{array}{c}\text { Australian } \\
\text { US }\end{array}$ & $\begin{array}{c}\text { Canadian } \\
\text { US }\end{array}$ \\
\hline Mine and Minerals & $21.59^{* * *}$ & $27.80^{* * * *}$ & 0.43 \\
Oil and Gas & $25.45^{* * *}$ & $14.55^{* * *}$ & 1.64 \\
Consumer Goods & $20.87^{* * *}$ & $17.16^{* * *}$ & 0.2 \\
Capital Goods & 2.75 & 1.27 & 0.29 \\
Basic Goods & $12.67^{* * *}$ & 1.85 & 4.93 \\
Financial Service & $5.57^{*}$ & 0 & $5.78^{*}$ \\
Diversified & $15.09^{* * *}$ & $9.27^{* *}$ & 0.74 \\
Stock Market Index & $29.24^{* * *}$ & $34.41^{* * *}$ & 0.24 \\
All Firms & $3.20^{* * *}$ & $6.26^{* * *}$ & $2.80^{* * *}$ \\
\hline
\end{tabular}

* All portfolio returns are in US dollars.

$*, * *, * * *$ denote the significance at the $0.05,0.01,0.001$ levels respectively.

across industries for the Australian portfolios varies between $0.16 \%$ (mines) to $1.41 \%$ (diversified) per month. In contrast, the mean returns for the US portfolios 
Table 4-b. Descriptive Statistics: Country and Industry Portfolios, January 1993 December 1997

Panel A: Mean and Standard Deviations

\begin{tabular}{|c|c|c|c|c|c|c|c|}
\hline \multirow{2}{*}{ Portfolio } & \multirow{2}{*}{$\begin{array}{c}\text { Number } \\
\mathrm{N}\end{array}$} & \multicolumn{2}{|c|}{ Australia } & \multicolumn{2}{|c|}{ Canada } & \multicolumn{2}{|c|}{ US } \\
\hline & & Mean & S.D. & Mean & S.D. & Mean & S.D. \\
\hline Mine and Minerals & 5 & 0.0045 & 0.083153 & 0.005477 & 0.060981 & 0.008041 & 0.050931 \\
\hline Oil and G & 2 & 0.0412 & 0.121801 & 0.013979 & 0.051811 & 0.005725 & 0.080971 \\
\hline Consumer Goods & 5 & 0.011793 & 0.056572 & 0.019567 & 0.060784 & 0.01 & 0.058064 \\
\hline Capital Goods & 5 & 0.006 & 0.068367 & 0.012318 & 0.05174 & 0.015 & 0.040911 \\
\hline Basic Goods & 5 & 0.009286 & 0.063769 & 0.014435 & 0.043686 & 0.020668 & 0.046818 \\
\hline Financial Service & 2 & 0.023357 & 0.055476 & 0.022327 & 0.052184 & 0.015745 & 0.05028 \\
\hline Diversified & 5 & 0.011508 & 0.069207 & 0.014907 & 0.045625 & 0.013136 & 0.050054 \\
\hline Stock Market Index & & 0.01053 & 0.049954 & 0.01253 & 0.040035 & 0.016395 & 0.031 \\
\hline
\end{tabular}

Panel B: Tests of the hypothesis of no difference in means of the matched industry portfolios (t-statistics)

\begin{tabular}{lccc}
\hline \multicolumn{1}{c}{ Portfolio } & $\begin{array}{c}\text { Australian } \\
\text { Canadian }\end{array}$ & Australian & Canadian \\
& -0.11 & US & US \\
\hline Mine and Minerals & 1.72 & -0.29 & -0.26 \\
Oil and Gas & -1.03 & 1.69 & 0.62 \\
Consumer Goods & -0.62 & -0.27 & 0.46 \\
Capital Goods & -0.66 & -0.88 & -0.39 \\
Basic Goods & 0.17 & -1.06 & -0.73 \\
Financial Service & -0.38 & 0.77 & 0.66 \\
Diversified & -0.39 & -0.15 & 0.21 \\
Stock Market Index & -0.99 & 1.30 \\
\hline
\end{tabular}

Panel C: Bartlett Test of the hypothesis of no difference in variance of the matched portfolios (F approximation)

\begin{tabular}{llll}
\hline \multicolumn{1}{c}{ Portfolio } & $\begin{array}{c}\text { Australian } \\
\text { Canadian }\end{array}$ & $\begin{array}{c}\text { Australian } \\
\text { US }\end{array}$ & $\begin{array}{c}\text { Canadian } \\
\text { US }\end{array}$ \\
\hline Mine and Minerals & $5.54^{*}$ & $13.53^{* * * *}$ & 1.89 \\
Oil and Gas & $38.41^{* * *}$ & $9.50^{* *}$ & $11.30^{* * *}$ \\
Consumer Goods & 0.30 & 0.04 & 0.12 \\
Capital Goods & $4.49^{*}$ & $14.80^{* * *}$ & 3.20 \\
Basic Goods & $8.18^{* *}$ & $5.50^{*}$ & 0.28 \\
Financial Service & 0.22 & 0.57 & 0.08 \\
Diversified & $9.88^{* *}$ & $6.04^{*}$ & 0.50 \\
Stock Market Index & 2.84 & $12.85^{* * *}$ & 3.79 \\
All Firms & $3.17^{* * *}$ & $4.91^{* * *}$ & $3.42^{* * *}$ \\
\hline
\end{tabular}

* All portfolio returns are in US dollars.

$*, * *, * * *$ denote the significance at the $0.05,0.01,0.001$ levels, respectively. 
range from $0 \%$ (oil) per month to $1.36 \%$ (consumer), and that for the Canadian portfolios from $-0.05 \%$ (mines) to $0.79 \%$ (consumer).

In contrast to the means, Panel $\mathrm{C}$ reveals that the variance of industry portfolios differs significantly across the three countries. The Australian industry portfolios have a much higher volatility than their US and Canadian counterparts; in some cases the Australian portfolios are twice as volatile as their matching Canadian and US portfolios. The differences in volatility between Canadian and US stocks, on the other hand, are insignificant in all cases except one (financial sector). This evidence suggests that the price of risk for Australian industry portfolios is different from that of the US or Canadian counterparts in the simple meanvariance framework.

The descriptive statistics for these portfolios in the 1993-97 period are provided in Table 4-b. With the exception of the Oil and Gas portfolio, both mean and variances of the Australian portfolios in this period are more in line with that of their US or Canadian counterparts. The Bartlett test statistics for testing the difference in variances in the 1993-97 period are generally much lower compared to that in the 1983-92 period in all cases except for the OIL and GAS portfolio. ${ }^{19}$ The volatility of the Australian stock market index return is also not statistically different from that of the Canadian stock market index return, although it is much higher than that of the US index return.

\section{Empirical Results}

\section{A. Pre-Specified Factors Approach}

The analysis in this section is performed using individual company data of 64 firms in each country matched on the basis of size and industry. The vector of Australian, Canadian, and US risk premia are estimated jointly with a seemingly unrelated cross-sectional regression model by using mean rates of stock returns as the dependent variables and estimated betas as the independent variables. We first conduct the test for all stocks in the 1983-92 period to examine the influence of industry or geographical distance on the tests of integration. Next, we undertake robustness tests by examining the sensitivity of the results to different subperiods.

\footnotetext{
${ }^{19}$ The results in the oil portfolio should be interpreted with caution since it contains only two stocks compared to 10 stocks in the earlier time period. The data in this period were available for only 40 Canadian firms, 45 US firms, 48 Australian firms, with a total of 29 matches across the three countries.
} 
Table 5. Multifactor Asset Pricing Model Risk Premia and Tests of Integration All Industries/Individual Company Data/1983-1992

The risk premia are estimated cross-sectionally using the estimated mean returns of the Australian, Canadian and US stocks as the dependent variable and the security betas of the 64 Australian, Canadian and US matched stocks as the independent variables. Betas are estimated with a multiple regression on the economic factors as the independent variables.

The economic factors (all in US\$) are:

METAL: Percentage change in the metal index.

OIL: $\quad$ Percentage change in the oil price.

INTMKT: Monthly rate of return on the Morgan Stanley Capital International (MSCI) index.

RESUS: Monthly return on the purely domestic component of the US market index orthogonal to INTMKT.

RESCDN: Monthly return on the purely domestic component of the Canadian market index orthogonal to INTMKT.

RESAUS: Monthly return on the purely domestic component of the Australian market index orthogonal to INTMKT.

Two tests of the equality of Risk Premia are reported: (a) all three countries risk premia on each factor are the same and (b) all three countries risk premia on each factor and the risk-free rates are the same.

Panel A: Risk Premia (t-statistics in parentheses)

\begin{tabular}{lccccccccc}
\hline & INTERCEPT & METAL & OIL & RESUS & RESCDN & RESAUS & $\begin{array}{c}\text { INT- } \\
\text { MKT }\end{array}$ & R $^{2}$ \\
\hline Aus- & 0.0198 & -0.0107 & -0.0188 & 0.0056 & -0.0029 & -0.0319 & 0.0150 & \multirow{2}{*}{0.37} \\
tralia & $(4.22)$ & $(-2.95)$ & $(-2.28)$ & $(2.06)$ & $(-0.89)$ & $(-3.61)$ & $(2.93)$ & \\
& & & & & & & & \\
Canada & 0.0048 & -0.0082 & -0.0010 & 0.0033 & -0.0000 & -0.0000 & 0.0000 & 0.05 \\
& $(1.03)$ & $(-1.53)$ & $(-0.13)$ & $(0.96)$ & $(-0.01)$ & $(-0.00)$ & $(0.00)$ & \\
United & 0.0027 & -0.0029 & 0.0035 & 0.0014 & -0.0090 & -0.0151 & 0.0051 & 0.22 \\
States & $(0.70)$ & $(-0.52)$ & $(0.41)$ & $(0.39)$ & $(-1.81)$ & $(-1.82)$ & $(1.04)$ & \\
\hline
\end{tabular}

Panel B: Tests of Equality of Risk Premia (Wald Tests - P-values in parentheses)

\begin{tabular}{cccccccc}
\hline Excluding Intercept $\left(\mathrm{H}_{0}: \lambda^{\mathrm{AUS}}=\lambda^{\mathrm{CAN}}=\lambda^{\mathrm{US}}\right)$ & $\begin{array}{c}\text { Including Intercept }\left(\mathrm{H}_{0}: \lambda^{\mathrm{AUS}}=\lambda^{\mathrm{CAN}}\right. \\
\left.=\lambda^{\mathrm{US}} \& \lambda_{0}^{\mathrm{AUS}}=\lambda_{0}^{\mathrm{CAN}}=\lambda_{0}^{\mathrm{US}}\right)\end{array}$ \\
\hline Aus/Can/US Aus/Can & Aus/US & Can/US & Aus/Can/US Aus/Can & $\begin{array}{c}\text { Aus/US } \\
\text { Can/ } \\
\text { US }\end{array}$ \\
\hline 18.255 & 13.778 & 12.205 & 3.618 & 41.057 & 20.198 & 30.876 & 10.083 \\
$(0.108)$ & $(0.032)$ & $(0.058)$ & $(0.728)$ & $(0.000)$ & $(0.005)$ & $(0.000)$ & $(0.184)$ \\
\hline
\end{tabular}

The results for the 1983-92 period are reported in Table 5. The estimates of risk premia and the t-statistics, obtained by ordinary least squares, are shown in Panel A. The Wald test statistics for testing the equality of risk premia across all the three 
countries as well as between pairs of countries are reported in Panel B.

The hypothesis that risk premia are the same across the Australian, Canadian and US stock markets is strongly rejected by the data (Panel B). The bilateral tests for the pairs of countries show that the rejection of integration comes primarily because the price of risk of Australian stocks is different from that of the matched Canadian and US stocks. For the Canadian and the US sample stocks, the hypothesis of equality of risk premia cannot be rejected at any conventional significance levels, irrespective of whether the intercept is included or excluded. That is not the case for the Australian stocks since the integration between the Australian and the US or the Canadian market is rejected in most cases.

Panel A shows that the sources of risk for Australian stocks are also significantly different from that of their Canadian or US counterparts. Most of the pre-specified factors are priced in the Australian sample while few are significant in the Canadian or U.S. case. The significant risk premia on the world stock market (INTMKT) as well as on other specified factors for the Australian stocks supports that Australian stocks are priced in a partially segmented global market. In contrast to the Australian case, none of the factors are significant for the US and Canadian sample at the 5\% level. For the US subsample, two factors, RESCDN and RESAUS, are significant at the $10 \%$ level but the sign of the risk premia is negative for both factors. A plausible explanation for the negative risk premia may be that since the US is a well-diversified economy, its stocks may be considered as hedges against the Australian and Canadian stocks that belong to predominantly resource-based economies. A somewhat surprising result is that neither the Canadian nor the US stocks have significant risk premia on the international index (INTMKT). The estimated intercept for the Australian stocks is also very high (about $2 \%$ per month) compared to that for the Canadian and US stocks.

Overall, these striking differences between the Australian and the US or Canadian stocks are consistent with the evidence of regional integration found in earlier studies. However, somewhat different expected signs for some factors as well as a significant intercept estimate for the Australian sample raises suspicion that some important factors may have been omitted in the Canadian and U.S. case. Alternatively, these results could also be induced by differences in the degree of integration across industries and time-periods. Further, the risk factors as well as the price of risk are also likely to vary across countries because barriers to international investments between the three countries may be falling at different rates. ${ }^{20}$ For example, Canada and the US have taken several steps in recent years

${ }^{20}$ See for example, Bekaert and Harvey (1995). 
to integrate the capital markets of the two countries including among others, the Canada-US Multi-jurisdictional Disclosure System implemented in 1991 that allows eligible firms from both countries to undertake cross-border issues in either country using the disclosure requirements of the home country. In the next section, we examine these issues by conducting integration tests in global and regional industry subsamples and in different subperiods.

\section{A.1 Global versus Regional Industry Stocks}

Table 6 presents the results in subsamples of global industries comprising of oil, mining, and financial sectors and of regional/local industries comprising of consumer goods, capital goods, basic goods and diversified sectors. The estimated risk premia for global and regional industry stocks in the 1983-92 subperiod are presented in Panel A. Further, two types of tests of equality of risk premia are conducted. First, the equality of risk premia is tested separately for global and regional industry stocks across the three countries. The Wald test statistics for the joint test across the three countries, as well as for different pairs of countries are presented in Panel B. Second, tests of equality of risk premia between global and regional industry stocks are also performed within each country and the Wald test

Table 6. Multifactor Asset Pricing Model Tests of Integration - Global Versus Regional Industries/Individual Company Data/Subperiod Analysis

The risk premia are estimated cross-sectionally using the estimated mean returns of the Australian, Canadian and US stocks as the dependent variable and the security betas of the 64 Australian, Canadian and US matched stocks as the independent variables. Betas are estimated with a multiple regression on the economic factors as the independent variables.

Differential risk premia are estimated for the group of industries classified as "global" (Mining, Oil and Financial Services) versus the remaining group of industries classified as "regional" (Basic Goods, Consumer, Capital Goods and Diversified/Miscellaneous).

The economic factors (all in US\$) are: METAL: Percentage change in the metal index; OIL: Percentage change in the oil price; INTMKT: Monthly rate of return on the Morgan Stanley Capital International (MSCI) index; RESUS: Monthly return on the purely domestic component of the US market index orthogonal to INTMKT; RESCDN: Monthly return on the purely domestic component of the Canadian market index orthogonal to INTMKT; RESAUS:

Monthly return on the purely domestic component of the Australian market index orthogonal to INTMKT.

Two tests of the equality of Risk Premia are reported: (a) all three countries risk premia on each factor are the same and (b) all three countries risk premia on each factor and the risk-free rates are the same. 
Panel A: Risk Premia (t-statistics in parentheses) 1983-92

\begin{tabular}{|c|c|c|c|c|c|c|c|c|}
\hline & INTERCEPT & METAL & OIL & RESUS & RESCDN & RESAUS & INTMKT & $\mathrm{R}^{2}$ \\
\hline \multicolumn{9}{|l|}{ Australia } \\
\hline $\begin{array}{l}\text { Global } \\
\text { Indus- } \\
\text { tries }\end{array}$ & $\begin{array}{c}0.0091 \\
(1.24)\end{array}$ & $\begin{array}{c}-0.0103 \\
(-1.91)\end{array}$ & $\begin{array}{c}-0.0106 \\
(-1.09)\end{array}$ & $\begin{array}{c}0.0042 \\
(0.99)\end{array}$ & $\begin{array}{c}-0.0108 \\
(-2.39)\end{array}$ & $\begin{array}{c}-0.0252 \\
(-1.80)\end{array}$ & $\begin{array}{l}0.0227 \\
(2.29)\end{array}$ & \\
\hline $\begin{array}{l}\text { Regional } \\
\text { Indus- } \\
\text { tries }\end{array}$ & $\begin{array}{c}0.0194 \\
(3.24)\end{array}$ & $\begin{array}{c}-0.0115 \\
(-2.47)\end{array}$ & $\begin{array}{c}-0.0152 \\
(-0.71)\end{array}$ & $\begin{array}{c}0.0022 \\
(0.62)\end{array}$ & $\begin{array}{c}0.0121 \\
(2.17)\end{array}$ & $\begin{array}{c}-0.0300 \\
(-2.69)\end{array}$ & $\begin{array}{c}0.0154 \\
(2.67)\end{array}$ & 0.47 \\
\hline \multicolumn{9}{|l|}{ Canada } \\
\hline $\begin{array}{l}\text { Global } \\
\text { Indus- } \\
\text { tries }\end{array}$ & $\begin{array}{c}0.0058 \\
(0.68)\end{array}$ & $\begin{array}{c}-0.0216 \\
(-2.52)\end{array}$ & $\begin{array}{c}-0.0151 \\
(-1.16)\end{array}$ & $\begin{array}{l}0.0113 \\
(2.01)\end{array}$ & $\begin{array}{c}-0.0030 \\
(-0.35)\end{array}$ & $\begin{array}{c}0.0108 \\
(0.59)\end{array}$ & $\begin{array}{c}0.0053 \\
(0.58)\end{array}$ & \\
\hline $\begin{array}{c}\text { Regional } \\
\text { Indus- } \\
\text { tries }\end{array}$ & $\begin{array}{c}0.0098 \\
(1.56)\end{array}$ & $\begin{array}{c}-0.0035 \\
(-0.49)\end{array}$ & $\begin{array}{c}0.0063 \\
(0.44)\end{array}$ & $\begin{array}{c}-0.0010 \\
(-0.22)\end{array}$ & $\begin{array}{c}-0.0029 \\
(-0.45)\end{array}$ & $\begin{array}{c}0.0031 \\
(0.17)\end{array}$ & $\begin{array}{c}-0.0024 \\
(-0.47)\end{array}$ & 0.16 \\
\hline $\begin{array}{l}\text { United } \\
\text { States }\end{array}$ & & & & & & & & \\
\hline $\begin{array}{l}\text { Global } \\
\text { Indus- } \\
\text { tries }\end{array}$ & $\begin{array}{c}-0.0090 \\
(-1.70)\end{array}$ & $\begin{array}{c}-0.0054 \\
(-0.81)\end{array}$ & $\begin{array}{c}-0.0055 \\
(-0.40)\end{array}$ & $\begin{array}{c}-0.0023 \\
(-0.44)\end{array}$ & $\begin{array}{c}-0.0045 \\
(-0.66)\end{array}$ & $\begin{array}{c}-0.0201 \\
(-1.70)\end{array}$ & $\begin{array}{c}0.0241 \\
(2.82)\end{array}$ & \\
\hline $\begin{array}{c}\text { Regional } \\
\text { Indus- } \\
\text { tries }\end{array}$ & $\begin{array}{c}0.0093 \\
(1.59)\end{array}$ & $\begin{array}{c}-0.0016 \\
(-0.18)\end{array}$ & $\begin{array}{c}-0.0000 \\
(-0.00)\end{array}$ & $\begin{array}{c}0.0022 \\
(0.47)\end{array}$ & $\begin{array}{c}-0.0110 \\
(-1.67)\end{array}$ & $\begin{array}{c}-0.0286 \\
(-2.29)\end{array}$ & $\begin{array}{c}-0.0026 \\
(-0.43)\end{array}$ & 0.33 \\
\hline
\end{tabular}

Panel B: Tests of Equality of Risk Premia across Countries (Wald Tests - P-values in parentheses) 1983-92

\begin{tabular}{|c|c|c|c|c|c|c|c|c|}
\hline & \multicolumn{4}{|c|}{ Excluding Intercept } & \multicolumn{4}{|c|}{ Including Intercept } \\
\hline & $\begin{array}{l}\text { Aus/ } \\
\text { Can/ } \\
\text { US }\end{array}$ & $\begin{array}{l}\text { Aus/ } \\
\text { Can }\end{array}$ & Aus/US & Can/US & $\begin{array}{l}\text { Aus/ } \\
\text { Can/ } \\
\text { US }\end{array}$ & Aus/Can & Aus/US & Can/US \\
\hline $\begin{array}{l}\text { Global Industrie } \\
\text { Risk Premia }\end{array}$ & $\begin{array}{r}\text { s } 10.336 \\
(0.587)\end{array}$ & $\begin{array}{l}4.558 \\
(0.602)\end{array}$ & $\begin{array}{c}5.370 \\
(0.497)\end{array}$ & $\begin{array}{c}6.052 \\
(0.417)\end{array}$ & $\begin{array}{l}25.046 \\
(0.034)\end{array}$ & $\begin{array}{c}4.562 \\
(0.713)\end{array}$ & $\begin{array}{l}10.361 \\
(0.169)\end{array}$ & $\begin{array}{l}10.161 \\
(0.180)\end{array}$ \\
\hline $\begin{array}{l}\text { Regional Indus- } \\
\text { tries Risk Premi }\end{array}$ & $\begin{array}{r}26.974 \\
a(0.008)\end{array}$ & $\begin{array}{l}14.195 \\
(0.028)\end{array}$ & $\begin{array}{l}22.948 \\
(0.001)\end{array}$ & $\begin{array}{c}3.174 \\
(0.787)\end{array}$ & $\begin{array}{l}38.556 \\
(0.000)\end{array}$ & $\begin{array}{l}23.454 \\
(0.001)\end{array}$ & $\begin{array}{l}37.972 \\
(0.000)\end{array}$ & $\begin{array}{c}5.404 \\
(0.611)\end{array}$ \\
\hline $\begin{array}{c}\text { Global and } \\
\text { Regional Indus- } \\
\text { tries Risk Premi }\end{array}$ & $\begin{array}{l}37.310 \\
a^{(0.041)}\end{array}$ & $\begin{array}{l}18.754 \\
(0.095)\end{array}$ & $\begin{array}{l}28.318 \\
(0.005)\end{array}$ & $\begin{array}{c}9.226 \\
(0.684)\end{array}$ & $\begin{array}{l}63.601 \\
(0.000)\end{array}$ & $\begin{array}{l}28.017 \\
(0.014)\end{array}$ & $\begin{array}{l}48.333 \\
(0.000)\end{array}$ & $\begin{array}{l}15.564 \\
(0.341)\end{array}$ \\
\hline
\end{tabular}


Panel C: Tests of Equality of Risk Premia Global=Regional by Country (Wald Tests - P-values in parentheses) 1983-92

\begin{tabular}{|c|c|c|c|c|c|}
\hline \multicolumn{3}{|c|}{ Excluding Intercept } & \multicolumn{3}{|c|}{ Including Intercept } \\
\hline $\begin{array}{c}\text { Australia } \\
{\left[\mathrm{H}_{0}: \lambda^{\mathrm{AUS}(\mathrm{G})}=\right.} \\
\left.\lambda^{\mathrm{AUS}(\mathrm{R})}\right]\end{array}$ & $\begin{array}{c}\text { Canada } \\
{\left[\mathrm{H}_{0}: \lambda^{\left.\operatorname{CAN(G)}=\lambda^{\operatorname{CAN}(\mathrm{R})}\right]}\right.}\end{array}$ & $\begin{array}{l}\text { United States } \\
{\left[\mathrm{H}_{0}: \lambda^{\mathrm{US}(\mathrm{G})}=\lambda^{\mathrm{US}(\mathrm{R})}\right]}\end{array}$ & $\begin{array}{c}\text { Australia } \\
{\left[\mathrm{H}_{0}: \lambda^{\mathrm{AUS}(\mathrm{G})}=\lambda^{\mathrm{AUS}(\mathrm{R})}\right.} \\
\left.\& \lambda_{0}{ }^{\mathrm{AUS}(\mathrm{G})}=\lambda_{0}{ }^{\mathrm{AUS}(\mathrm{R})}\right]\end{array}$ & $\begin{array}{c}\text { Canada } \\
{\left[\mathrm{H}_{0}: \lambda^{\operatorname{CAN}(G)}=\lambda^{\operatorname{CAN}(R)} \&\right.} \\
\left.\left.\lambda_{0}{ }^{\operatorname{CAN}(G)=}=\lambda_{0}{ }^{\operatorname{CAN}(\mathrm{R})}\right]\right]\end{array}$ & $\begin{array}{l}\text { United States } \\
{\left[\mathrm{H}_{0}: \lambda^{\mathrm{US}(\mathrm{G})}=\lambda^{\mathrm{US}(\mathrm{R})}\right.} \\
\left.\left.\& \lambda_{0}{ }^{\mathrm{US}(\mathrm{G})}=\lambda_{0}{ }^{\mathrm{US}(\mathrm{R})}\right]\right]\end{array}$ \\
\hline $\begin{array}{l}12.772 \\
(0.047)\end{array}$ & $\begin{array}{c}8.054 \\
(0.234)\end{array}$ & $\begin{array}{l}11.493 \\
(0.074)\end{array}$ & $\begin{array}{l}13.259 \\
(0.066)\end{array}$ & $\begin{array}{c}8.232 \\
(0.313)\end{array}$ & $\begin{array}{l}11.505 \\
(0.118)\end{array}$ \\
\hline
\end{tabular}

Panel D: Tests of Equality of Risk Premia across Countries (Wald Tests - P-values in parentheses) 1983 - 1987:09

\begin{tabular}{|c|c|c|c|c|c|c|}
\hline & \multicolumn{3}{|c|}{ Excluding Intercept } & \multicolumn{3}{|c|}{ Including Intercept } \\
\hline & $\begin{array}{c}\text { Aus/Can/ } \\
\text { US }\end{array}$ & Aus/Can & Aus/US Can/US & $\begin{array}{c}\text { Aus/Can/ } \\
\text { US }\end{array}$ & Aus/Can & Aus/USCan/US \\
\hline $\begin{array}{l}\text { Global Indus- } \\
\text { tries } \\
\text { Risk Premia }\end{array}$ & $\begin{array}{l}14.692 \\
(0.259)\end{array}$ & $\begin{array}{c}5.410 \\
(0.492)\end{array}$ & $\begin{array}{cc}12.019 & 2.867 \\
(0.062) & (0.825)\end{array}$ & $\begin{array}{l}22.425 \\
(0.070)\end{array}$ & $\begin{array}{c}5.484 \\
(0.601)\end{array}$ & $\begin{array}{cc}15.887 & 8.259 \\
(0.026) & (0.310)\end{array}$ \\
\hline $\begin{array}{l}\text { Regional Indus- } \\
\text { tries Risk Pre- } \\
\text { mia }\end{array}$ & $\begin{array}{l}44.576 \\
(0.000)\end{array}$ & $\begin{array}{l}16.408 \\
(0.012)\end{array}$ & $\begin{array}{cc}33.964 & 17.405 \\
(0.000) & (0.008)\end{array}$ & $\begin{array}{l}63.368 \\
(0.000)\end{array}$ & $\begin{array}{l}30.377 \\
(0.000)\end{array}$ & $\begin{array}{ll}48.970 & 20.570 \\
(0.000) & (0.004)\end{array}$ \\
\hline $\begin{array}{l}\text { Global and } \\
\text { Regional Indus- } \\
\text { tries Risk Pre- } \\
\text { mia }\end{array}$ & $\begin{array}{l}59.267 \\
(0.000)\end{array}$ & $\begin{array}{l}21.819 \\
(0.040)\end{array}$ & $\begin{array}{ll}45.982 & 20.273 \\
(0.000) & (0.062)\end{array}$ & $\begin{array}{l}85.793 \\
(0.000)\end{array}$ & $\begin{array}{l}35.862 \\
(0.001)\end{array}$ & $\begin{array}{cc}64.857 & 28.829 \\
(0.000) & (0.011)\end{array}$ \\
\hline
\end{tabular}

Panel E: Tests of Equality of Risk Premia across Countries (Wald Tests - P-values in parentheses) 1988 - 1992

\begin{tabular}{cccccccccc}
\hline \multicolumn{3}{c}{ Excluding Intercept } & \multicolumn{5}{c}{ Including Intercept } \\
\hline \multicolumn{1}{c}{$\begin{array}{c}\text { Aus/Can/ } \\
\text { US }\end{array}$} & Aus/Can & Aus/US & Can/US & $\begin{array}{c}\text { Aus/Can/ } \\
\text { US }\end{array}$ & Aus/Can & Aus/US & Can/US \\
\hline Global & 20.061 & 10.117 & 5.881 & 10.816 & 24.386 & 10.136 & 10.075 & 11.023 \\
Industries & $(0.066)$ & $(0.120)$ & $(0.437)$ & $(0.094)$ & $(0.041)$ & $(0.181)$ & $(0.184)$ & $(0.138)$ \\
$\begin{array}{c}\text { Risk Premia } \\
\text { Regional }\end{array}$ & 36.605 & 23.423 & 25.997 & 10.533 & 37.892 & 25.854 & 29.661 & 12.545 \\
$\begin{array}{c}\text { Industries } \\
\text { Risk Premia } \\
\text { Global and } \\
\text { Regional }\end{array}$ & $56.000)$ & $(0.001)$ & $(0.000)$ & $(0.104)$ & $(0.001)$ & $(0.001)$ & $(0.000)$ & $(0.084)$ \\
Industries & $(0.000)$ & $(0.001)$ & $(0.001)$ & $(0.045)$ & $(0.000)$ & $(0.001)$ & $(0.000)$ & $(0.052)$ \\
Risk Premia & & & & & & & & & \\
\hline
\end{tabular}


Panel F: Tests of Equality of Risk Premia across Countries (Wald Tests - P-values in parentheses) 1993 - 1997

\begin{tabular}{cccccccccc}
\hline & \multicolumn{3}{c}{ Excluding Intercept } & \multicolumn{5}{c}{ Including Intercept } \\
\hline \multicolumn{3}{c}{$\begin{array}{c}\text { Aus/Can/ } \\
\text { US }\end{array}$} & Aus/Can & Aus/US & Can/US & $\begin{array}{c}\text { Aus/Can/ } \\
\text { US }\end{array}$ & Aus/Can & Aus/US & Can/US \\
\hline Global & 35.791 & 15.774 & 23.820 & 8.379 & 40.663 & 18.870 & 23.824 & 8.433 \\
Industries & $(0.000)$ & $(0.015)$ & $(0.001)$ & $(0.212)$ & $(0.000)$ & $(0.009)$ & $(0.001)$ & $(0.296)$ \\
$\begin{array}{c}\text { Risk Premia } \\
\text { Regional }\end{array}$ & 36.137 & 16.635 & 11.436 & 26.383 & 76.084 & 17.145 & 35.439 & 34.180 \\
Industries & $(0.000)$ & $(0.011)$ & $(0.076)$ & $(0.000)$ & $(0.000)$ & $(0.016)$ & $(0.000)$ & $(0.000)$ \\
Risk Premia & & & & & & & & \\
$\begin{array}{c}\text { Global and } \\
\text { Regional }\end{array}$ & 71.929 & 32.410 & 35.257 & 34.762 & 116.747 & 36.015 & 59.264 & 42.614 \\
Industries & $(0.000)$ & $(0.001)$ & $(0.000)$ & $(0.001)$ & $(0.000)$ & $(0.001)$ & $(0.000)$ & $(0.000)$ \\
Risk Premia & & & & & & & & \\
\hline
\end{tabular}

Panel G: Tests of Equality of Risk Premia Global=Regional by Country

(Wald Tests - P-values in parentheses) 1983 - 1987:09

\begin{tabular}{|c|c|c|c|c|c|}
\hline \multicolumn{3}{|c|}{ Excluding Intercept } & \multicolumn{3}{|c|}{ Including Intercept } \\
\hline $\begin{array}{c}\text { Australia } \\
{\left[\mathrm{H}_{0}: \lambda^{\mathrm{AUS}(\mathrm{G})}=\lambda^{\mathrm{AUS}(\mathrm{R})}\right]}\end{array}$ & $\begin{array}{c}\text { Canada } \\
: \lambda^{\operatorname{CAN}(G)}=\lambda^{\operatorname{CAN(R)}}\end{array}$ & $\begin{array}{l}\text { United States } \\
{\left[\mathrm{H}_{0}: \lambda^{\mathrm{US}(\mathrm{G})=} \lambda^{\mathrm{US}(\mathrm{R})}\right]}\end{array}$ & $\begin{array}{c}\text { Australia } \\
{\left[\mathrm{H}_{0}: \lambda^{\mathrm{AUS}(\mathrm{G})}=\lambda^{\mathrm{AUS}(\mathrm{R})}\right.} \\
\left.\& \lambda_{0}{ }^{\mathrm{AUS}(\mathrm{G})}=\lambda_{0}{ }^{\mathrm{AUS}(\mathrm{R})}\right]\end{array}$ & $\begin{array}{c}\text { Canada } \\
{\left[\mathrm{H}_{0}: \lambda^{\operatorname{CAN}(G)=} \lambda^{\operatorname{CAN}(R)}\right.} \\
\left.\left.\& \lambda_{0}{ }^{\operatorname{CAN}(G)=}=\lambda_{0}^{\operatorname{CAN}(R)}\right]\right]\end{array}$ & $\begin{array}{l}\text { United States } \\
{\left[\mathrm{H}_{0}: \lambda^{\mathrm{US}(\mathrm{G})}=\lambda^{\mathrm{US}(\mathrm{R})}\right.} \\
\left.\left.\& \lambda_{0}^{\mathrm{US}(\mathrm{G})}=\lambda_{0}^{\mathrm{US}(\mathrm{R})}\right]\right]\end{array}$ \\
\hline $\begin{array}{l}39.702 \\
(0.000)\end{array}$ & $\begin{array}{c}6.402 \\
(0.379)\end{array}$ & $\begin{array}{l}18.402 \\
(0.005)\end{array}$ & $\begin{array}{l}42.575 \\
(0.000)\end{array}$ & $\begin{array}{c}6.832 \\
(0.447)\end{array}$ & $\begin{array}{l}18.952 \\
(0.008)\end{array}$ \\
\hline \multicolumn{3}{|c|}{ Excluding Intercept } & \multicolumn{3}{|c|}{ Including Intercept } \\
\hline $\begin{array}{c}\text { Australia } \\
{\left[\mathrm{H}_{0}: \lambda^{\mathrm{AUS}(\mathrm{G})}=\lambda^{\mathrm{AUS}(\mathrm{R})}\right]}\end{array}$ & 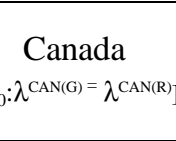 & $\begin{array}{l}\text { United States } \\
{\left[\mathrm{H}_{0}: \lambda^{\mathrm{US}(\mathrm{G})}=\lambda^{\mathrm{US}(\mathrm{R})}\right]}\end{array}$ & $\begin{array}{c}\text { Australia } \\
{\left[\mathrm{H}_{0} \cdot \lambda^{\mathrm{AUS}(\mathrm{G})}=\lambda^{\mathrm{AUS}(\mathrm{R})}\right.} \\
\left.\& \lambda_{0}{ }^{\mathrm{AUS}(\mathrm{G})}=\lambda_{0}^{\mathrm{AUS}(\mathrm{R})}\right]\end{array}$ & $\begin{array}{c}\text { Canada } \\
{\left[\mathrm{H}_{0}: \lambda^{\operatorname{CAN}(G)=} \lambda^{\operatorname{CAN}(R)}\right.} \\
\left.\left.\& \lambda_{0}{ }^{\operatorname{CAN}(G)}=\lambda_{0}{ }^{\operatorname{CAN}(R)}\right]\right]\end{array}$ & $\begin{array}{l}\text { United States } \\
{\left[\mathrm{H}_{0}: \lambda^{\mathrm{US}(\mathrm{G})}=\lambda^{\mathrm{US}(\mathrm{R})}\right.} \\
\left.\left.\& \lambda_{0}{ }^{\mathrm{US}(\mathrm{G})}=\lambda_{0}{ }^{\mathrm{US}(\mathrm{R})}\right]\right]\end{array}$ \\
\hline $\begin{array}{c}5.000 \\
(0.020)\end{array}$ & $\begin{array}{l}25.546 \\
(0.000)\end{array}$ & $\begin{array}{c}5.611 \\
(0.468)\end{array}$ & $\begin{array}{l}20.758 \\
(0.004)\end{array}$ & $\begin{array}{l}26.318 \\
(0.000)\end{array}$ & $\begin{array}{l}12.099 \\
(0.097)\end{array}$ \\
\hline
\end{tabular}

Panel H: Tests of Equality of Risk Premia Global=Regional by Country (Wald Tests - P-values in parentheses) 1988 - 1992

\begin{tabular}{|c|c|c|c|c|c|}
\hline \multicolumn{3}{|c|}{ Excluding Intercept } & \multicolumn{3}{|c|}{ Including Intercept } \\
\hline $\begin{array}{c}\text { Australia } \\
{\left[\mathrm{H}_{0}: \lambda^{\mathrm{AUS}(\mathrm{G})}=\lambda^{\mathrm{AUS}(\mathrm{R})}\right]}\end{array}$ & $\begin{array}{c}\text { Canada } \\
\left.\mathrm{H}_{0}: \lambda^{\mathrm{CAN}(\mathrm{G})}=\lambda^{\mathrm{CAN}(\mathrm{R})}\right)\end{array}$ & $\begin{array}{l}\text { United States } \\
{\left[\mathrm{H}_{0}: \lambda^{\mathrm{US}(\mathrm{G})}=\lambda^{\mathrm{US}(\mathrm{R})}\right]}\end{array}$ & $\begin{array}{c}\text { Australia } \\
{\left[\mathrm{H}_{0}: \lambda^{\mathrm{AUS}(\mathrm{G})}=\lambda^{\mathrm{AUS}(\mathrm{R})}\right.} \\
\left.\& \lambda_{0}{ }^{\mathrm{AUS}(\mathrm{G})}=\lambda_{0}{ }^{\mathrm{AUS}(\mathrm{R})}\right]\end{array}$ & $\begin{array}{c}\text { Canada } \\
{\left[\mathrm{H}_{0}: \lambda^{\operatorname{CAN}(\mathrm{G})=} \lambda^{\mathrm{CAN}(\mathrm{R})}\right.} \\
\left.\left.\& \lambda_{0}{ }^{\operatorname{CAN}(\mathrm{G})}=\lambda_{0}{ }^{\operatorname{CAN}(\mathrm{R})}\right]\right]\end{array}$ & $\begin{array}{l}\text { United States } \\
{\left[\mathrm{H}_{0}: \lambda^{\mathrm{US}(\mathrm{G})}=\lambda^{\mathrm{US}(\mathrm{R})}\right.} \\
\left.\left.\& \lambda_{0}{ }^{\mathrm{US}(\mathrm{G})}=\lambda_{0}{ }^{\mathrm{US}(\mathrm{R})}\right]\right]\end{array}$ \\
\hline $\begin{array}{l}16.760 \\
(0.010)\end{array}$ & $\begin{array}{l}17.139 \\
(0.009)\end{array}$ & $\begin{array}{l}19.009 \\
(0.004)\end{array}$ & $\begin{array}{l}17.218 \\
(0.016)\end{array}$ & $\begin{array}{l}17.142 \\
(0.017)\end{array}$ & $\begin{array}{l}20.161 \\
(0.005)\end{array}$ \\
\hline
\end{tabular}


Panel I: Tests of Equality of Risk Premia Global=Regional by Country

(Wald Tests - P-values in parentheses) 1993 - 1997

Panel J: Tests of Equality of Risk Premia Global=Regional by Country

(Wald Tests - P-values in parentheses) 1988 - 1992

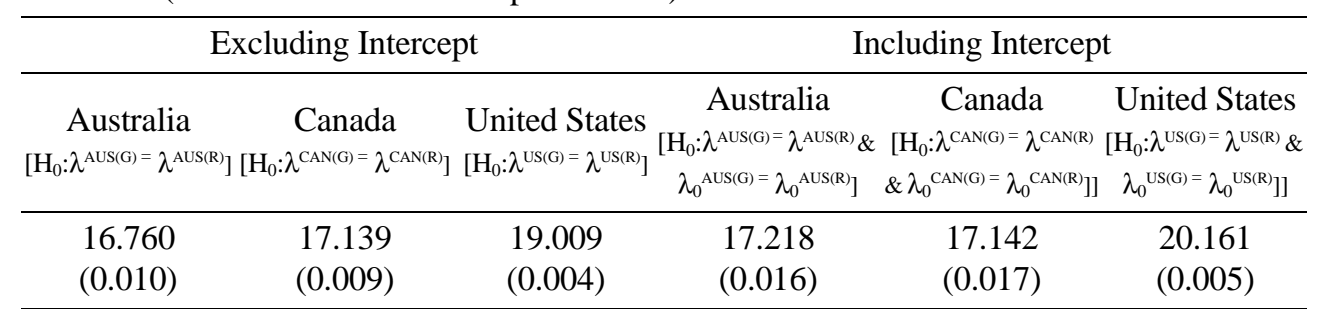

Panel K: Tests of Equality of Risk Premia Global=Regional by Country

(Wald Tests - P-values in parentheses) 1993 - 1997

\begin{tabular}{|c|c|c|c|c|c|}
\hline $\begin{array}{c}\text { Australia } \\
{\left[\mathrm{H}_{0}: \lambda^{\mathrm{AUS}(\mathrm{G})=} \lambda^{\mathrm{AUS}(\mathrm{R})}\right]}\end{array}$ & $\begin{array}{c}\text { Canada } \\
{\left[\mathrm{H}_{0}: \lambda^{\left.\operatorname{CAN(G)}=\lambda^{\operatorname{CAN(R)}}\right]}\right.}\end{array}$ & $\begin{array}{l}\text { United States } \\
{\left[\mathrm{H}_{0}: \lambda^{\mathrm{US}(\mathrm{G})}=\lambda^{\mathrm{US}(\mathrm{R})}\right]}\end{array}$ & $\begin{array}{c}\text { Australia } \\
{\left[\mathrm{H}_{0}: \lambda^{\mathrm{AUS}(\mathrm{G})=}=\lambda^{\mathrm{AUS}(\mathrm{R})} \&\right.} \\
\left.\lambda_{0}^{\mathrm{AUS}(\mathrm{G})}=\lambda_{0}^{\mathrm{AUS}(\mathrm{R})}\right]\end{array}$ & 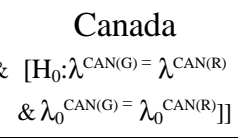 & $\begin{array}{r}\text { United States } \\
{\left[\mathrm{H}_{0}: \lambda^{\mathrm{US}(\mathrm{G})=} \lambda^{\mathrm{US}(\mathrm{R})} \&\right.} \\
\left.\left.] \quad \lambda_{0}{ }^{\mathrm{US}(\mathrm{G})}=\lambda_{0}^{\mathrm{US(R)}}\right]\right]\end{array}$ \\
\hline $\begin{array}{c}5.000 \\
(0.020)\end{array}$ & $\begin{array}{l}25.546 \\
(0.000)\end{array}$ & $\begin{array}{c}5.611 \\
(0.468)\end{array}$ & $\begin{array}{l}20.758 \\
(0.004)\end{array}$ & $\begin{array}{l}26.318 \\
(0.000)\end{array}$ & $\begin{array}{r}12.099 \\
(0.097)\end{array}$ \\
\hline
\end{tabular}

statistics for these are presented in Panel C.

The evidence in Table 6 supports that global industry stocks are priced in a relatively integrated global market compared to their regional industry counterparts. For global industry stocks, the equality of risk premia is strongly supported across the three countries as well as between pairs of countries (Panel B). This is not the case for the regional industry stocks. The equality of risk premia across all the three countries is rejected at any conventional significance level in all tests, both including and excluding the intercept. The bilateral tests show that the rejection of integration across three countries is driven primarily by the differences in pricing between the Australian regional stocks and their North American counterparts. The US and Canadian regional industry stocks are priced in an integrated North American market in all tests, including or excluding intercept.

The analysis of risk premia in Panel A shows that sources of risk are also different for global and regional industry stocks. For global industry stocks, INTMKT is a common source of risk and its coefficient is positive for all countries although it is significant only for the Australian and US subsamples. METAL is another common source of risk for all global industry stocks and it has a negative premium for all countries and is significant for the Australian and Canadian stocks. For the Canadian global stocks, RESUS (rather than INTMKT) is the most significant source of risk which suggests that the Canadian market may be integrated only regionally and not 
globally. In contrast, there are few common sources of risk for the regional industry stocks across the three countries. For example, most factors are important for the Australian regional industries while none of the specified factors seem to matter for their Canadian counterparts. For the US regional stocks, RESCDN and RESAUS are the only important sources of risk. These results suggest that our specified factors may not fully capture important sources of risk, especially in the Canadian and U.S. case.

\section{A.2 Different Time Periods}

To examine the sensitivity of our results to different time periods, we repeat the analysis of subsection A.1 for the two subperiods: 1983-87 and 1988-92. ${ }^{20} \mathrm{In}$ addition, we also test the robustness of our results by conducting the tests in the 1993-97 period. For brevity, only the Wald test statistics for equality of risk premia across countries and industries in different subperiods are reported and these are presented in Table 6, Panels D-I.

The results in both subperiods are generally consistent with those in the 198392 period. The evidence is generally supportive of the notion that global industry stocks are priced in relatively integrated markets while the regional industry stocks are priced in segmented markets in both subperiods. There are, however, some mixed results in the 1993-97 period. For example, the support for the equality of risk premia for the global stocks is weaker in the 1993-97 subperiod compared to that in the earlier 1983-92 period, contrary to the prediction of increasing integration over time. Further, the equality of risk premia for the Canadian and US regional industry stocks is also rejected in this period. One plausible explanation could be that the sources of risk may be very different in the subperiods and may not be fully captured by our pre-specified factors, especially in the case of the regional industry subsample. ${ }^{21}$

\section{B. Factor Analytic Approach}

For our final piece of empirical analysis, factors are extracted using the twentyone industry portfolios from the three countries in the sample. The matrix of factor

\footnotetext{
${ }^{20}$ We exclude the period surrounding the October 1987 stock market crash in the 1983-87 subperiod.

${ }^{21}$ The sources of risk for the global industry stocks vary substantially across countries in different time periods but for the regional industry stocks there are hardly any common sources of risk across the three countries. A lack of any common factors and the significant changes in the estimated risk premia as well as puzzling signs for some coefficients indicate that the estimates for regional industry stocks may not be very reliable.
} 
loadings is estimated by using a maximum likelihood factor analysis and an orthogonal Varimax rotation. Five factors, with eigenvalues greater than one, are used for the analysis. An examination of the extracted factors indicates that the first factor has heavy loadings on the US and Canadian stocks while the second is concentrated on the Australian stocks. These two factors could be interpreted as proxying the North American and Australian stock market, respectively. The next two factors could be interpreted as proxying the oil and mining factors as these are dominated by oil and mining stocks respectively from all countries. The fifth factor is heavily loaded on five Canadian portfolios (except mining and oil) and could thus be interpreted as a factor proxying the Canadian stock market factor. Although one need to exercise caution in the interpretation of these factors because of their non-uniqueness, there appears to be some correspondence between the prespecified factors and the factors extracted in the factor analytic procedure.

The empirical results for tests of integration in the factor analytic framework in the 1983-92 period are presented in Table 7. Overall, the results are generally consistent with those obtained in the pre-specified factor approach; namely, that global and regional industry stocks are priced in different markets and the Canadian and US stocks are priced in regionally integrated markets. The evidence supports that the global industry stocks are priced in an integrated capital market,

Table 7. Factor Analytic Tests of Integration - Individual Company Data/1983-1992

The risk premia are estimated cross-sectionally using the estimated mean returns of the Australian, Canadian and US stocks as the dependent variable and the security betas of the 64 Australian, Canadian and US matched stocks as the independent variables. Betas are estimated with a multiple regression on five factors (extracted using factor analysis) as the independent variables. Differential risk premia are estimated for the group of industries classified as "global" (Mining, Oil and Financial Services) versus the remaining group of industries classified as "regional" (Basic Goods, Consumer, Capital Goods and Diversified/Miscellaneous).

Two tests of the equality of Risk Premia are reported: (a) all three countries risk premia on each factor are the same and (b) all three countries risk premia on each factor and the risk-free rates are the same.

Panel A: Tests of Equality of Risk Premia (Wald Tests - P-values in parentheses)

\begin{tabular}{|c|c|c|c|c|c|}
\hline $\begin{array}{c}\text { Excluding } \mathrm{I} \\
\left(\mathrm{H}_{0}: \lambda^{\mathrm{AUS}}=\lambda\right.\end{array}$ & $\begin{array}{l}\text { atercept } \\
\left.\text { CAN }=\lambda^{\mathrm{US}}\right)\end{array}$ & $\left(\mathrm{H}_{0}: \lambda^{\mathrm{AUS}}\right.$ & $\begin{array}{l}\text { Includin } \\
{ }^{\mathrm{CAN}}=\lambda^{\mathrm{US}}\end{array}$ & ntercept & $\left.\mathrm{N}=\lambda_{0}^{\mathrm{US}}\right)$ \\
\hline Aus/Can/US Aus/Can & Aus/US Can/US & Aus/Can/US & Aus/Can & Aus/US & Can/US \\
\hline $\begin{array}{l}20.743 \\
(0.023)\end{array}$ & $\begin{array}{cc}9.365 & 5.015 \\
(0.095) & (0.414)\end{array}$ & $\begin{array}{l}29.016 \\
(0.004)\end{array}$ & $\begin{array}{l}24.907 \\
(0.000)\end{array}$ & $\begin{array}{l}18.134 \\
(0.006)\end{array}$ & $\begin{array}{c}5.268 \\
(0.510)\end{array}$ \\
\hline
\end{tabular}


Panel B: Tests of Equality of Risk Premia across Countries (Wald Tests - P-values in parentheses)

\begin{tabular}{lcccccccc}
\hline & \multicolumn{3}{c}{ Excluding Intercept } & \multicolumn{5}{c}{ Including Intercept } \\
\hline & $\begin{array}{c}\text { Aus/Can/ } \\
\text { US }\end{array}$ & Aus/Can Aus/US & Can/US & $\begin{array}{c}\text { Aus/Can/ } \\
\text { US }\end{array}$ & Aus/Can Aus/US Can/US & C \\
& & & & & & \\
\hline Global Industries & 5.562 & 3.384 & 2.657 & 2.102 & 7.416 & 3.473 & 3.198 & 3.309 \\
Risk Premia & $(0.851)$ & $(0.641)$ & $(0.753)$ & $(0.835)$ & $(0.829)$ & $(0.748)$ & $(0.784)$ & $(0.769)$ \\
Regional Indus- & 22.173 & 16.487 & 12.031 & 5.047 & 35.642 & 25.478 & 22.123 & 5.208 \\
tries Risk Premia & $(0.014)$ & $(0.006)$ & $(0.034)$ & $(0.410)$ & $(0.000)$ & $(0.000)$ & $(0.001)$ & $(0.517)$ \\
Global and & 27.735 & 19.871 & 14.688 & 7.149 & 43.058 & 28.951 & 25.321 & 8.517 \\
$\begin{array}{l}\text { Regional Indus- } \\
\text { tries Risk Premia }\end{array}$ & $(0.116)$ & $(0.030)$ & $(0.144)$ & $(0.711)$ & $(0.010)$ & $(0.004)$ & $(0.013)$ & $(0.744)$ \\
\hline
\end{tabular}

Panel C: Tests of Equality of Risk Premia Global=Regional by Country (Wald Tests - P-values in parentheses)

\begin{tabular}{|c|c|c|c|c|c|}
\hline \multicolumn{3}{|c|}{ Excluding Intercept } & \multicolumn{3}{|c|}{ Including Intercept } \\
\hline $\begin{array}{c}\text { Australia } \\
{\left[\mathrm{H}_{0}: \lambda^{\mathrm{AUS}(\mathrm{G})}=\right.} \\
\left.\lambda^{\mathrm{AUS}(\mathrm{R})}\right]\end{array}$ & $\begin{array}{c}\text { Canada } \\
{\left[\mathrm{H}_{0}: \lambda^{\mathrm{CAN}(\mathrm{G})}=\right.} \\
\left.\lambda^{\mathrm{CAN}(\mathrm{R})}\right]\end{array}$ & $\begin{array}{c}\text { United } \\
\text { States } \\
{\left[\mathrm{H}_{0}: \lambda^{\mathrm{US}(\mathrm{G})}=\right.} \\
\left.\lambda^{\mathrm{US}(\mathrm{R})}\right]\end{array}$ & $\begin{array}{c}\text { Australia } \\
{\left[\mathrm{H}_{0}: \lambda^{\mathrm{AUS}(\mathrm{G})}=\right.} \\
\begin{array}{c}\lambda^{\mathrm{AUS}(\mathrm{R})} \& \lambda_{0}^{\mathrm{AUS}(\mathrm{G})} \\
\left.=\lambda_{0}{ }^{\mathrm{AUS}(\mathrm{R})}\right]\end{array}\end{array}$ & $\begin{array}{c}\text { Canada } \\
{\left[\mathrm{H}_{0}: \lambda^{\mathrm{CAN}(\mathrm{G})}=\right.} \\
\lambda^{\mathrm{CAN}(\mathrm{R})} \& \\
\lambda_{0}^{\mathrm{CAN}(\mathrm{G})}= \\
\left.\left.\lambda_{0}^{\mathrm{CAN}(\mathrm{R})}\right]\right]\end{array}$ & $\begin{array}{c}\text { United } \\
\text { States } \\
{\left[\mathrm{H}_{0}: \lambda^{\mathrm{US}(\mathrm{G})=}=\lambda^{\mathrm{US}(\mathbb{R}}\right.} \\
\& \lambda_{0}^{\mathrm{US(G)}}= \\
\left.\left.\lambda_{0}{ }^{\mathrm{USR}(\mathrm{R})}\right]\right]\end{array}$ \\
\hline $\begin{array}{c}8.300 \\
(0.140)\end{array}$ & $\begin{array}{c}9.623 \\
(0.087)\end{array}$ & $\begin{array}{l}12.366 \\
(0.030)\end{array}$ & $\begin{array}{c}9.092 \\
(0.168)\end{array}$ & $\begin{array}{c}9.628 \\
(0.141)\end{array}$ & $\begin{array}{l}12.859 \\
(0.045)\end{array}$ \\
\hline
\end{tabular}

irrespective of their country of domicile. None of the Wald test-statistics are significant at any conventional significance levels, both excluding and including intercept. These results hold in the joint tests of integration across the three countries as well as in the bilateral tests among pairs of countries. In contrast, for the regional industry stocks, the equality of risk premia is rejected in all cases, except in the US Canada case. Interestingly, the equality of risk premia between the global and regional industry stocks is rejected for both Australia and Canada but not for the US (Panel C). A plausible explanation could be that because the US economy constitutes a large proportion of the world economy, it is less influenced by global factors and more by the domestic factors.

Finally, the results in different subperiods are presented in Table 8, Panels A-F. Overall, the results in both subperiods 1983-87 and 1988-92 confirm global industry stocks are priced largely in integrated capital markets, while regional industry stocks (except in the Canada - US case) are priced in segmented markets in both subperiods. More importantly, unlike in the pre-specified factor approach, 
Table 8. Factor Analytic Tests of Interationm- Global versus Regional Industries/ Individual Company Data/Subperiod Analysis

The risk premia are estimated cross-sectionally using the estimated mean returns of the Australian, Canadian and US stocks as the dependent variable and the security betas of the 64 Australian, Canadian and US matched stocks as the independent variables. Betas are estimated with a multiple regression on five factors (extracted using factor analysis) as the independent variables.

Differential risk premia are estimated for the group of industries classified as "global" (Mining, Oil and Financial Services) versus the remaining group of industries classified as "regional" (Basic Goods, Consumer, Capital Goods and Diversified/Miscellaneous).

Two tests of the equality of Risk Premia are reported: (a) all three countries risk premia on each factor are the same and (b) all three countries risk premia on each factor and the risk-free rates are the same.

Panel A: Tests of Equality of Risk Premia across Countries

(Wald Tests - P-values in parentheses) 1983 - 1987:09

\begin{tabular}{lccccccccc}
\hline & \multicolumn{4}{c}{ Excluding Intercept } & \multicolumn{5}{c}{ Including Intercept } \\
\hline & $\begin{array}{c}\text { Aus/Can/ } \\
\text { US }\end{array}$ & Aus/Can Aus/US & Can/US & $\begin{array}{c}\text { Aus/Can/ } \\
\text { US }\end{array}$ & $\begin{array}{c}\text { Aus/ } \\
\text { Can }\end{array}$ & Aus/US & Can/US \\
\hline Global Industries & 13.936 & 5.267 & 10.213 & 5.189 & 15.638 & 5.550 & 11.220 & 7.134 \\
Risk Premia & $(0.176)$ & $(0.384)$ & $(0.069)$ & $(0.393)$ & $(0.208)$ & $(0.475)$ & $(0.082)$ & $(0.309)$ \\
Regional Indust & 34.195 & 18.990 & 29.651 & 5.208 & 52.579 & 36.648 & 44.769 & 7.913 \\
Risk Premia & $(0.000)$ & $(0.002)$ & $(0.000)$ & $(0.391)$ & $(0.000)$ & $(0.000)$ & $(0.000)$ & $(0.245)$ \\
Global\&Reg Ind & 48.131 & 24.257 & 39.863 & 10.396 & 68.216 & 42.199 & 55.989 & 15.047 \\
Risk Premia & $(0.000)$ & $(0.007)$ & $(0.000)$ & $(0.406)$ & $(0.000)$ & $(0.000)$ & $(0.000)$ & $(0.239)$ \\
\hline
\end{tabular}

Panel B: Tests of Equality of Risk Premia across Countries (Wald Tests - P-values in parentheses) 1988 - 1992

\begin{tabular}{lccccccccc}
\hline & \multicolumn{4}{c}{ Excluding Intercept } & \multicolumn{5}{c}{ Including Intercept } \\
\hline & $\begin{array}{c}\text { Aus/Can/ } \\
\text { US }\end{array}$ & Aus/Can Aus/US & Can/US & $\begin{array}{c}\text { Aus/Can/ } \\
\text { US }\end{array}$ & $\begin{array}{c}\text { Aus/ } \\
\text { Can }\end{array}$ & Aus/US & Can/US \\
\hline Global Industries & 21.088 & 17.662 & 3.715 & 10.480 & 26.957 & 19.214 & 8.025 & 10.481 \\
Risk Premia & $(0.020)$ & $(0.003)$ & $(0.591)$ & $(0.063)$ & $(0.008)$ & $(0.004)$ & $(0.236)$ & $(0.106)$ \\
Regional Indust & 52.851 & 39.497 & 19.964 & 19.342 & 65.132 & 50.811 & 27.439 & 21.529 \\
Risk Premia & $(0.000)$ & $(0.000)$ & $(0.001)$ & $(0.002)$ & $(0.000)$ & $(0.000)$ & $(0.000)$ & $(0.001)$ \\
Global\&Reg Ind & 73.939 & 57.159 & 23.678 & 29.822 & 92.089 & 70.026 & 35.464 & 32.010 \\
Risk Premia & $(0.000)$ & $(0.000)$ & $(0.009)$ & $(0.001)$ & $(0.000)$ & $(0.000)$ & $(0.000)$ & $(0.001)$ \\
\hline
\end{tabular}


Panel C: Tests of Equality of Risk Premia across Countries (Wald Tests - P-values in parentheses) 1993 - 1997

\begin{tabular}{lccccccccc}
\hline & \multicolumn{3}{c}{ Excluding Intercept } & \multicolumn{5}{c}{ Including Intercept } \\
\hline & $\begin{array}{c}\text { Aus/Can/ } \\
\text { US }\end{array}$ & Aus/Can Aus/US & Can/US & $\begin{array}{c}\text { Aus/Can/ } \\
\text { US }\end{array}$ & $\begin{array}{c}\text { Aus/ } \\
\text { Can }\end{array}$ & Aus/US & Can/US \\
\hline Global Industries & 4.997 & 3.115 & 1.624 & 1.244 & 7.238 & 3.504 & 6.527 & 1.320 \\
Risk Premia & $(0.891)$ & $(0.682)$ & $(0.898)$ & $(0.940)$ & $(0.841)$ & $(0.743)$ & $(0.366)$ & $(0.970)$ \\
Regional Indust & 43.33738 & 8.240 & 25.818 & 26.705 & 83.71685 & 9.310 & 44.926 & 29.916 \\
Risk Premia & $(0.000)$ & $(0.143)$ & $(0.000)$ & $(0.000)$ & $(0.000)$ & $(0.156)$ & $(0.000)$ & $(0.000)$ \\
Global\&Reg Ind & 48.334 & 11.356 & 27.443 & 27.950 & 90.955 & 12.815 & 51.454 & 31.236 \\
Risk Premia & $(0.000)$ & $(0.330)$ & $(0.002)$ & $(0.002)$ & $(0.000)$ & $(0.383)$ & $(0.000)$ & $(0.002)$ \\
\hline
\end{tabular}

Panel D: Tests of Equality of Risk Premia Global=Regional by Country (Wald Tests - P-values in parentheses) 1983 - 1987: 09

\begin{tabular}{|c|c|c|c|c|c|}
\hline \multicolumn{3}{|c|}{ Excluding Intercept } & \multicolumn{3}{|c|}{ Including Intercept } \\
\hline $\begin{array}{c}\text { Australia } \\
{\left[\mathrm{H}_{0}: \lambda^{\mathrm{AUS}(\mathrm{G})}=\lambda^{\mathrm{AUS}(\mathrm{R})}\right]}\end{array}$ & $\begin{array}{c}\text { Canada } \\
{\left[\mathrm{H}_{0}: \lambda^{\mathrm{CAN}(\mathrm{G})}=\right.} \\
\left.\lambda^{\mathrm{CAN(R)}]}\right]\end{array}$ & $\begin{array}{l}\text { United States } \\
{\left[\mathrm{H}_{0}: \lambda^{\mathrm{US}(\mathrm{G})=} \lambda^{\mathrm{US}(\mathrm{R})}\right]}\end{array}$ & $\begin{array}{c}\text { Australia } \\
{\left[\mathrm{H}_{0}: \lambda^{\operatorname{AUS}(\mathrm{G})}=\lambda^{\operatorname{AUS}(\mathrm{R})} \&\right.} \\
\left.\lambda_{0}{ }^{\mathrm{AUS}(\mathrm{G})}=\lambda_{0}^{\operatorname{AUS}(\mathrm{R})}\right]\end{array}$ & $\begin{array}{c}\text { Canada } \\
\begin{array}{c}{\left[\mathrm{H}_{0}: \lambda^{\operatorname{CAN}(\mathrm{G})}=\lambda^{\operatorname{CAN}(\mathrm{R})} \&\right.} \\
\left.\left.\lambda_{0}{ }^{\mathrm{CAN}(\mathrm{G})}=\lambda_{0}^{\mathrm{CAN}(\mathrm{R})}\right]\right]\end{array}\end{array}$ & $\begin{array}{c}\text { United States } \\
{\left[\mathrm{H}_{0}: \lambda^{\mathrm{US}(\mathrm{G})}=\lambda^{\mathrm{US}(\mathrm{R})} \&\right.} \\
\left.\left.\lambda_{0}{ }^{\mathrm{US}(\mathrm{G})}=\lambda_{0}{ }^{\mathrm{US}(\mathrm{R})}\right]\right]\end{array}$ \\
\hline $\begin{array}{l}25.025 \\
(0.000)\end{array}$ & $\begin{array}{c}7.632 \\
(0.178)\end{array}$ & $\begin{array}{l}20.041 \\
(0.001)\end{array}$ & $\begin{array}{l}29.085 \\
(0.000)\end{array}$ & $\begin{array}{c}7.742 \\
(0.258)\end{array}$ & $\begin{array}{c}20.284 \\
(0.002)\end{array}$ \\
\hline
\end{tabular}

Panel E: Tests of Equality of Risk Premia Global=Regional by Country (Wald Tests - P-values in parentheses) 1988 - 1992

\begin{tabular}{|c|c|c|c|c|c|}
\hline \multicolumn{3}{|c|}{ Excluding Intercept } & \multicolumn{3}{|c|}{ Including Intercept } \\
\hline $\begin{array}{c}\text { Australia } \\
{\left[\mathrm{H}_{0}: \lambda^{\mathrm{AUS}(\mathrm{G})}=\lambda^{\mathrm{AUS}(\mathrm{R})}\right]}\end{array}$ & $\begin{array}{c}\text { Canada } \\
{\left[\mathrm{H}_{0}: \lambda^{\mathrm{CAN}(\mathrm{G})=}\right.} \\
\left.\lambda^{\mathrm{CAN(R)}]}\right]\end{array}$ & $\begin{array}{l}\text { United States } \\
{\left[\mathrm{H}_{0}: \lambda^{\mathrm{US}(\mathrm{G})}=\lambda^{\mathrm{US}(\mathrm{R})}\right]}\end{array}$ & $\begin{array}{c}\text { Australia } \\
{\left[\mathrm{H}_{0}: \lambda^{\mathrm{AUS}(\mathrm{G})}=\lambda^{\mathrm{AUS}(\mathrm{R})} \&\right.} \\
\left.\lambda_{0}{ }^{\mathrm{AUS}(\mathrm{G})}=\lambda_{0}{ }^{\mathrm{AUS}(\mathrm{R})}\right]\end{array}$ & $\begin{array}{c}\text { Canada } \\
\&\left[\mathrm{H}_{0}: \lambda^{\mathrm{CAN}(\mathrm{G})}=\lambda^{\operatorname{CAN}(\mathrm{R})} \&\right. \\
\left.\left.\lambda_{0}{ }^{\mathrm{CAN}(\mathrm{G})}=\lambda_{0}{ }^{\mathrm{CAN(R)}}\right]\right]\end{array}$ & $\begin{array}{c}\text { United States } \\
\begin{array}{c}{\left[\mathrm{H}_{0}: \lambda^{\mathrm{US}(\mathrm{G})}=\lambda^{\mathrm{US}(\mathrm{R})} \&\right.} \\
\left.\left.\lambda_{0}^{\mathrm{US}(\mathrm{G})}=\lambda_{0}^{\mathrm{US}(\mathrm{R})}\right]\right]\end{array}\end{array}$ \\
\hline $\begin{array}{l}12.281 \\
(0.031)\end{array}$ & $\begin{array}{l}21.221 \\
(0.001)\end{array}$ & $\begin{array}{c}6.791 \\
(0.237)\end{array}$ & $\begin{array}{l}14.065 \\
(0.029)\end{array}$ & $\begin{array}{l}21.334 \\
(0.002)\end{array}$ & $\begin{array}{c}7.473 \\
(0.279)\end{array}$ \\
\hline
\end{tabular}

Panel F: Tests of Equality of Risk Premia Global=Regional by Country

(Wald Tests - P-values in parentheses) 1993 - 1997

\begin{tabular}{|c|c|c|c|c|c|}
\hline \multicolumn{3}{|c|}{ Excluding Intercept } & \multicolumn{3}{|c|}{ Including Intercept } \\
\hline $\begin{array}{c}\text { Australia } \\
{\left[\mathrm{H}_{0}: \lambda^{\mathrm{AUS}(\mathrm{G})}=\lambda^{\mathrm{AUS}(\mathrm{R})}\right]}\end{array}$ & $\begin{array}{c}\text { Canada } \\
{\left[\mathrm{H}_{0}: \lambda^{\mathrm{CAN}(\mathrm{G})}=\right.} \\
\left.\lambda^{\mathrm{CAN}(\mathrm{R})}\right]\end{array}$ & $\begin{array}{l}\text { United States } \\
{\left[\mathrm{H}_{0}: \lambda^{\mathrm{US}(\mathrm{G})}=\lambda^{\mathrm{US}(\mathrm{R})}\right]}\end{array}$ & $\begin{array}{c}\text { Australia } \\
{\left[\mathrm{H}_{0}: \lambda^{\operatorname{AUS}(\mathrm{G})=} \lambda^{\operatorname{AUS}(\mathrm{R})} \&\right.} \\
\left.\lambda_{0}^{\mathrm{AUS}(\mathrm{G})=} \lambda_{0}^{\operatorname{AUS}(\mathrm{R})}\right]\end{array}$ & $\begin{array}{c}\text { Canada } \\
{\left[\begin{array}{c}\mathrm{H}_{0}: \lambda^{\operatorname{CAN}(\mathrm{G})}=\lambda^{\mathrm{CAN}(\mathrm{R})} \& \\
\left.\left.\lambda_{0}{ }^{\mathrm{CAN}(\mathrm{G})}=\lambda_{0}{ }^{\mathrm{CAN}(\mathrm{R})}\right]\right]\end{array}\right.}\end{array}$ & $\begin{array}{c}\text { United States } \\
{\left[\mathrm{H}_{0}: \lambda^{\mathrm{US}(\mathrm{G})}=\lambda^{\mathrm{US}(\mathrm{R})} \&\right.} \\
\left.\left.\lambda_{0}{ }^{\mathrm{US}(\mathrm{G})}=\lambda_{0}{ }^{\mathrm{US}(\mathrm{R})}\right]\right]\end{array}$ \\
\hline $\begin{array}{l}13.532 \\
(0.018)\end{array}$ & $\begin{array}{l}12.853 \\
(0.024)\end{array}$ & $\begin{array}{c}2.245 \\
(0.814)\end{array}$ & $\begin{array}{l}15.692 \\
(0.016)\end{array}$ & $\begin{array}{l}19.725 \\
(0.003)\end{array}$ & $\begin{array}{c}4.795 \\
(0.570)\end{array}$ \\
\hline
\end{tabular}

the main findings in the 1983-92 period are also strongly supported in the 199397 period. For global industry stocks, integration in the 1993-97 is supported in all tests including the joint tests for all the three countries. For the regional industry 
stocks, the equality of risk premia is supported only in one case, namely, the bilateral tests between Australia and Canada. The evidence also confirms that the Canadian and US stocks are priced in a regionally integrated market, irrespective of their industry. Further, the equality of risk premia for regional and global industry stocks within each country is not supported by the data, except in the case of the US. The differences in results in the pre-specified factor and factor analytic approaches in this case raise suspicion that some important risk factors may be omitted in the pre-specified factor approach.

\section{Summary and Conclusions}

There is an ever-growing literature examining the issue of how integrated the "world's" financial markets have become, particularly in the context of the globalization occurring throughout the 1980s and 1990s. Although, most studies support a move toward integration of the country markets, some puzzling evidence such as a strong home bias in investor portfolios that is inconsistent with these findings remains unresolved. Further, while bilateral tests of integration support a move toward integration over time for different country markets, the tests in multi-country settings suggest that the standard asset pricing models may hold regionally but not globally. Many recent studies have examined the role of industry and geographical proximity in international stock returns and crossborder equity flows. Our study complements this literature by exploring whether these factors could also potentially explain unequal integration across securities observed in the tests of integration using standard asset pricing models.

We examine the influence of these factors using a matched sample by size and industry across three developed capital markets (Australia, Canada and the US). The tests are conducted in the multi-factor pricing framework using both prespecified factors and a factor analytic approach by conducting a three-way analysis across the three countries over the period 1983 to 1992 and robustness tests in the 1993-97 period. Specifically, we focus on three questions: (a) whether the three capital markets are integrated with global markets and with each other; (b) whether the degree of integration varies across geographical distance; and (c) whether the degree of integration varies across global and regional industries.

Our investigation supports two main findings. First, our evidence supports that pricing of Australian stocks is different from that of their Canadian and U.S. 
counterparts. The Australian stocks are priced in a partially segmented global market whereas the Canadian stocks are priced in a regionally integrated North American stock market. Second, our evidence also suggests that the degree of integration may vary across industries. Specifically, we find that global industry stocks such as oil and mining stocks are priced in a relatively integrated capital market compared to their regional industry counterparts. This evidence supports the notion that industry and geographical distance may proxy important sources of risk that are not accounted for in the standard asset pricing models commonly used in the tests of market integration.

Our results should be interpreted with some caution because of several limitations of our research design. First, our tests of integration are joint tests of market integration and the hypothesized asset pricing model. A lack of significance of most pre-specified factors in our tests in the Canadian and U.S. sample indicates that we may have omitted some important factors in the multifactor pricing framework. Further, our tests also do not account for change in risk factors and risk premia that are also likely to vary over time. Second, the distinction between global and regional sectors in our sample is not based on any clear criteria and is somewhat arbitrary. Also, our industry classifications are very broad and cover only a few industries that may have reduced power of our tests to distinguish between the country and industry effects. Finally, although we have controlled for key factors such as size and industry in matching firms across countries, these controls are likely to be imperfect.

Despite these limitations, our results are useful and interesting in furthering research in international asset pricing. The evidence of home bias puzzle and mixed evidence on tests of capital market integration shows that identifying sources of risk when international capital markets are segmented is a challenging task for researchers. Our modest aim in this study is to explore some potential avenues that may provide some fruitful directions for future research in this area. Our evidence of differential pricing of Australian versus Canadian and U.S. stocks and of global versus regional industry stocks suggests that industry and geographical proximity may proxy important determinants of asset pricing in the international setting. Future studies should investigate this issue more fully in different country settings employing finer industry partitions and asset pricing models that incorporate time varying risk premia. 


\section{Acknowledgments}

The authors gratefully acknowledge helpful comments on previous versions of this paper from Rob Brooks, Madhu Kalimpialli, Lorenzo Garlappi, an anonymous reviewer, and participants at the meetings of the Northern Finance Association, European Financial Management Association, and Multinational Financial Society. Part of this research was completed while Robert Faff was visiting the Department of Accounting and Finance at the University of Strathclyde. Usha Mittoo acknowledges financial support from the Social Sciences and Humanities Research Council of Canada, the Centre for International Business Studies, and the Bank of Montreal Professorship.

\section{References}

Arshanapalli, B., J. Doukas, and L.H.P. Lang, (1997), "Common Volatility in the Industrial Structure of Global Capital Markets," Journal of International Money and Finance, 16, 189-209.

Banz, R.W., (1981), "The Relationship Between Return and Market Value of Common Stocks," Journal of Financial Economics, 9, 3-18.

Bekaert, G., and C. Harvey, (1995), “Time Varying World Market Integration,” Journal of Finance, 50, 403-444.

Brennan, M.J., and H.H. Cao, (1997), "International Portfolio Investment Flows,” Journal of Finance, 52, 1851-1880.

Campbell, J.Y., and Y. Hamao, (1992), "Predictable Stock Returns in the United States and Japan: A Study of Long-Term Market Capital Market Integration," Journal of Finance, 47, 43-69.

Cho, D., C. Eun, and L. Senbet, (1986), "International Arbitrage Pricing Theory: An Empirical Investigation," Journal of Finance, 41, 313-330.

Choi, J., and M. Rajan, (1997), “A Joint Test of Market Segmentation and Exchange Risk Factor in International Capital Markets," Journal of International Business Studies, 29-49.

Conner, G., (1984), “A Unified Beta Pricing Theory,” Journal of Economic Theory, 13-31. Cooper, Ian A., and Evi Kaplanis, (1994), "Home bias in equity portfolios, inflation hedging, and international capital market equilibrium," Review of Financial Studies, 7, 45-60.

Coval, J. D., and T. J. Moskowitz, (1999), "Home Bias at Home: Local Equity Preference in Domestic Portfolios," Journal of Finance, 54, 1-39.

Drummen, M., and H. Zimmerman, (1992), "The Structure of European Stock Returns," Financial Analyst Journal, 48, 15-26. 
French, Kenneth R., and James M. Poterba, (1991), "Investor Diversification and International Equity Markets, American Economic Review, Papers and Proceedings, 81, 222-226.

Froot, K., P. O'Connel1, and M. Seasholes, (2001), “ The Portfolio Flows of International Investors", Journal of Financial Economics, 59, 151-193.

Gehrig, T., (1993), “An Information based explanation of the Domestic Bias in International equity Investment," Scandinavian Journal of Economics, 95, 97-109.

Griffin, J. M., and G. A. Karolyi, (1998), “Another Look at the Role of the Industrial Structure of Markets for International Diversification Strategies", Journal of Financial Economics, 50, 351-373.

Grinold, R., A. Rudd, and D. Stefek, (1989), “Global Factors: Fact or Fiction?”, Journal of Portfolio Management, 16, 79-88.

Gultekin, M.N, N.B. Gultekin and A. Penati, (1989), "Capital Controls and International Capital Market Segmentation: The Evidence from the Japanese and American Stock Markets," Journal of Finance, 44, 849-869.

Huberman, G., (2001), "Familiarity Breeds Investment," Review of Financial Studies, 14, 659-680.

Heston, S., and G. Rouwenhorst, (1994), "Does Industrial Structure Explain the Benefits of International Diversification?" Journal of Financial Economics, 36, 3-27.

Jorion, P., and E. Schwartz, (1986), "Integration Versus Segmentation in the Canadian Stock Market," Journal of Finance, 41, 603-613.

Kang, J.K., and R.M. Stulz, (1997), "Why is There a Home Biqs? An Analysis of Foreign Portfolio equity Ownership in Japan," Journal of Financial Economics, 46, 3-28.

Korajczyk, R. and C. Viallet, (1989), "An Empirical Investigation of International Asset Pricing," Review of Financial Studies, 2, 553-587.

Koutoulas, G. and Kryzanowski, L., (1994), "Integration or Segmentation of the Canadian Stock Market: Evidence Based on the APT", Canadian Journal of Economics, 27, 329-351.

Lessard, D. R., (1974), “World, National and Industry Factors in Equity Returns,” Journal of Finance, 29, 379-391.

Merton, R., (1987), “A Simple Model of Capital Market Equilibrium with Incomplete Information", Journal of Finance, 42, 483-510.

Mittoo, U., (1992), “Additional Evidence on Integration in the Canadian Stock Market," Journal of Finance, 47, 2035-2054.

Portes, R., and H. Rey, (2001), "The Determinants of Cross-Border Equity Flows," Working Paper, CEPR and NBER.

Roll, R., (1992), "Industrial Structure and the Comparative Behavior of International Stock Market Indices", Journal of Finance, 47, 3-42.

Solnik, B., de Freitas, A., (1988), "International Factors of Stock Price Behavior," in: Khoury, S., Ghosh, A. (Eds.), Recent Developments in International Banking and Finance. D.C. Heath, New York, 259-276.

Stulz, R., (1995), “International Portfolio Choice and Asset Pricing: An Integrative 
Survey," in Jarrow, Robert Vojislav Maksimovic and William Ziemba, eds.: Finance, Handbooks in Operations Research and Management Science, Vol. 9, (ElsevierNorth Holland, Amsterdam).

Tesar, Linda L., and Ingrid Werner, (1995), "Home Bias and High Turnover," Journal of International Money \& Finance, 14, 467-492. 